\title{
Værdikamp på revolutionstiden
}

\section{Striden om en ny kirkeliturgi i Haderslev Provsti 1797-98}

\section{Af Lars N. HenNingsen}

En folkelig protestbevægelse greb Sonderjylland sidst i 1790'erne. Anledningen var en reform af gudstjenestens indretning. Regeringen i Kobenhavn blev så bekymret over uroen, at den tillod noget ganske usædvanligt: De enkelte menigheder fik lov til at holde sogneafstemninger for eller imod nyordningen. Det førte til sammenstød mellem befolkning, præster og embedsmænd og til det første eksempel på en bred folkelig petitionsbevægelse, som kendes i Sønderjyllands historie. I artiklen oprulles forløbet på Haderslev-egnen. Den stedlige amtmand Møsting blev sat på en vanskelig opgave. Hvordan skulle han kunne repræsentere en kongelig magtfuldkommenhed, når den enevældige konge overlod det til folket at afgøre sagerne med fri afstemning?

Ved nytårstide 1798 blev en "oplyst « gudstjenestereform lanceret $\mathrm{i}$ alle kirker mellem Kongeåen og Elben. Næppe var det sket, før forskellige samfundsgrupper lå $\mathrm{i}$ strid om reformen. Det gjaldt $\mathrm{i}$ begge de to hertugdømmer Slesvig og Holsten. Her vil vi holde os til Haderslevegnen.

Bønderne protesterede mod det nye, og præsterne var forargede. »Opviglere agiterer for den gamle gudstjenesteordning. I 17 år har jeg virket for at udrydde fordomme, men jeg måtte give op, « skrev pastor Claudi i Åstrup i 1799. »Jeg har måttet følge nabosognene og opgive reformen, men nogle overtroiske sædvaner har jeg dog kunnet afskaffe," lød det fra pastor Lautrup i Tyrstrup. "Pøbelen af alle stænder aner ikke den uvidenhed, den stikker $i$, de træges og stupides og folkebedragernes trøst frygter og hader enhver forbedring. Der er mange, som finder en interesse $i$, at alt bliver ved det gamle og sædvanen, og det af bigot fastholden ved det tilvante, af mangel på kendskab til det bedre. Af egennyttig, herskesyg egoisme er de fjender af det sande og bedre, " udtalte pastor J. Chr. Jessen i Stenderup om sin menighed. I Ødis mente pastor Magnus Gottlieb Chemnitz, at hans 
menighed repræsenterede »den for alle rå og udannede mennesker særegne afvisning af enhver så velgørende fornyelse i kirke- og skolesager. $\ll^{1}$

Amtmand Møsting i Haderslev var lige så opbragt. Han så protesterne som anstiftet af "ondsindede personer ", »bandeførere", »opviglere ", "urolige hoveder ", som såede tvedragtens sæd og forledte den rolige befolkning til misnøje.

Landboerne på deres side påstod, at det nye var et angreb på den rene lutherske lære, udtænkt af de lokale gejstlige og amtmanden. De protesterede og klagede direkte til kongen i København.

Konfrontationen strakte sig over hele året 1798. Den har bemærkelsesværdige ingredienser: Øvrigheden prøvede at påvirke stemningen ved at uddele trykte "propagandapjecer" $\mathrm{i}$ landbefolkningen. Det er vist første gang, noget sådant blev forsøgt. Landboerne samledes til by- og sognemøder, holdt lokale afstemninger og sendte andragender til øvrigheden underskrevet af et flertal af beboerne. En så bred demokratisk bevægelse, formuleret nedefra af landboerne selv, kendes ikke tidligere på vore kanter. Herfra kan trækkes en linje til senere tiders politiske petitionsbevægelser og til vor tids demokratiske samfund. Der er derfor god grund til at se nærmere på konflikten, her afgrænset til dens forløb i Haderslev Provsti. ${ }^{2}$

\section{En oplyst kirkereform}

Slesvig sidst i 1700-årene gik for at være en oplyst provins. »Folk ser ud, som om de har åbent øje for forbedringer, de er hverken stivnet i uvidenhed eller knuget af slaveriets usselhed. Jeg blev behageligt overrasket ved at fornemme en sådan opblomstrende velstand i denne del af Tyskland. Ja, jeg er overbevist om, at den almindelige oplysning i høj grad gør fremskridt i dette land. Sandelig, Kongen af Danmarks tyske besiddelse, Holsten [her menes Slesvig (LH)], syntes mig at være langt fremme for nogen del, jeg havde set, af kongeriget ...«; sådan vurderede den engelske forfatterinde og pioner for kvindebevægelsen Mary Wollstonecraft Sønderjylland efter et besøg kort før $1796 .^{3}$

Oplysningen havde fat i præsterne. I mange år havde de savnet en alment gældende ritualbog, som angav, hvordan gudstjenesten skulle forløbe. De forskrifter, som fandtes, var af ældre dato og tog ikke hensyn til smag og ideer sidst i 1700-årene ${ }^{4}$. Fra 1780'erne tog nogle 
præster på egen hånd initiativ til småændringer for at gøre gudstjenesten mere »tidssvarende" og fjerne uforståelige eller gammeldags elementer. Pastor Oest i Nykirke i Angel har berettet om, hvordan præster i Angel foretog gradvise "moderniseringer«. Omkring 1790 stod skriftestolene i hans og nabosognenes kirker ubenyttede, fordi præsterne ikke længere holdt privat skriftemål med syndsforladelse og håndspålæggelse. I stedet blev kommende altergæster lørdagen før altergang samlet til en forberedelsestale, såkaldt alment skriftemål. Flere af præsterne indførte et mere varieret salmevalg end før, og de blev mere tilbageholdende med at slå korsets tegn. ${ }^{5}$ Sådanne lokale initiativer medvirkede til at skabe betydelige forskelle på gudstjenesten fra kirke til kirke.

Fra 1773 var begge hertugdømmer Slesvig og Holsten samlet under kongen. $\mathrm{Nu}$ tog kirkeledelsen i Kobenhavn fat på at få gjort gudstjenesten mere ensartet. I 1794 fik den nytiltrådte generalsuperintendent (biskop) J.G.C. Adler til opgave at udtænke en moderniseret gudstjenesteordning. Adler havde en tekst færdig i sommeren 1796, og den 18. november blev den godkendt i statens øverste myndighed, statsrådet. Den 2. december tilgik der overkonsistorierne i hertugdømmerne et reskript om, at den nye agende var godkendt som norm for alle kirker. ${ }^{6}$

Adlers »Slesvig-Holstenske Kirke-Agende« var et barn af oplysningstiden. Gudstjenesten blev mere afvekslende og mangfoldig. Den fjernede uforståelige og mystiske ord og vendinger, der kunne fremme overtro og ikke passede til tidens smag og dannelse. ${ }^{7}$ Hidtil blev der ofte sunget op til fem og altid de samme salmer ved gudstjenesten; menigheden kunne dem udenad. Fremover skulle der kun synges to salmer ved en gudstjeneste, og de skulle passe til søndagens prædikentema. Bønner, evangelier eller epistler skulle ikke længere messes eller synges for alteret, de skulle læses op. Præsten skulle ikke stå så meget vendt mod alteret, men henvende sig direkte til menigheden. De tilvante tekstrækker blev ændret, og der skulle prædikes over både evangelier og epistler. Benyttelsen af fadervor blev begrænset. Bønnen skulle ikke bedes både før og efter prædiken og måske endnu en gang sidst i gudstjenesten, men kun én gang, efter prædiken. Præsten kunne vælge moderne omskrivninger af bønnen i stedet for formuleringen i Det nye Testamente. Privatskriftemål med syndsbekendelse og præstens håndspålæggelse og absolution skulle erstattes af et "almindeligt skriftemål«, dvs. en skriftetale og forberedelse 


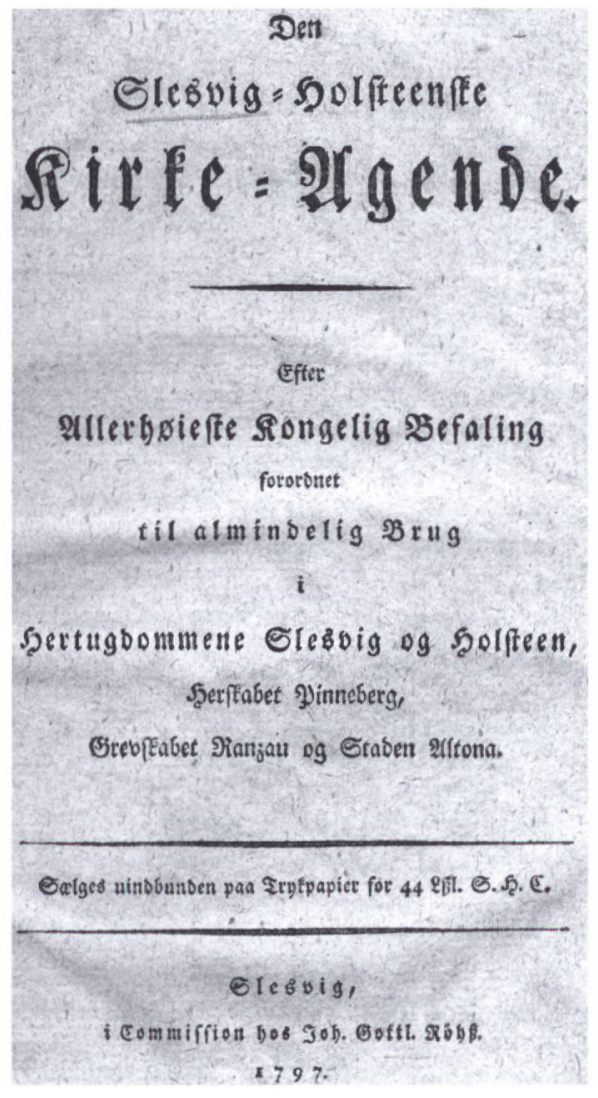

Generalsuperintendent Adlers kirkeritual eller agende udkom $1797 i$ både tysk og dansk udgave. Den var afslutningen på et forarbejde gennem mange år og skulle skabe ensartethed $i$ kirkeskikkene og omformulere de ældre alterbøger til et tidssvarende sprog.

forud for nadveren. Denne skulle holdes sjældnere end før, hver sjette eller tolvte søndag eller forår og efterår et par søndage efter hinanden. Der blev givet nye formularer til brug ved de forskellige kirkelige handlinger, dåb, konfirmation, vielse osv. Den mosaiske eller aronitiske velsignelse ${ }^{8}$ blev anset for uforståelig og anbefalet ændret til et velsignelsesønske. At slå korsets tegn skulle ophøre - det var et levn fra katolsk tid.

I april 1797 var ritualbogen trykt og blev udsendt til de tysksprogede menigheder. Pastor Peter Prahl i Vedsted oversatte teksten til dansk til brug for de dansksprogede menigheder. I oktober $1797 \mathrm{blev}$ denne danske udgave fordelt til præsterne. Lovgiveren var sig bevidst, at en så radikal omlægning af den tilvante gudstjeneste kunne fremkalde modstand. Derfor skulle præsterne ikke anprise det nye 


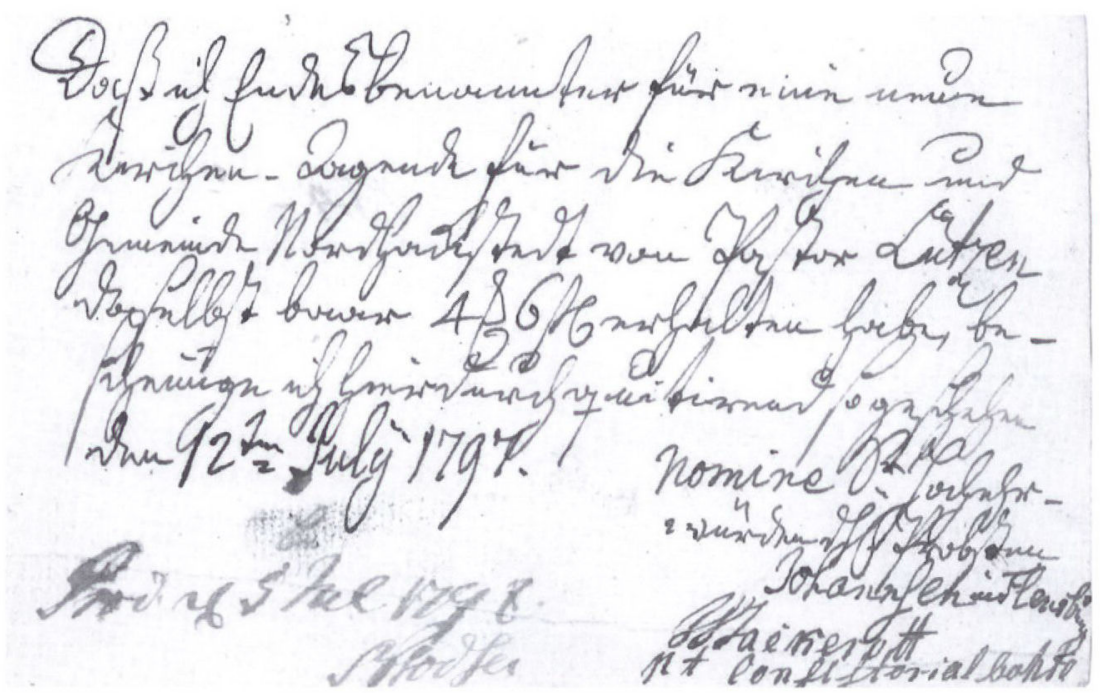

Hver prast skulle have et eksemplar af den nye agende, indkøbt på kirkekassens regning. Her ses regnskabsbilaget fra Nørre Haksted i Sydslesvig for udgiften til bogkøbet. Arkivet ved Dansk Centralbibliotek for Sydslesvig.

udtrykkeligt fra prædikestolen. De skulle blot tage det nye i brug i al stilhed, så ubemærket som muligt. Gudstjenesten efter de nye regler skulle begynde 1 . januar 1798 . For at foregribe problemer fik sognefolkene lov til at få udført kirkelige handlinger, som angik dem selv, dåb og vielse, efter de gammelkendte formularer. Det almene skriftemål skulle indføres, men derudover skulle det stadig være muligt at skrifte privat; benyttelsen af de nye tekstrækker skulle forberedes gradvist. ${ }^{9}$

Også før havde ændringer i kirkelivet fremkaldt protester fra en konservativt indstillet landbefolkning. Det fik to moderne indstillede præster, Jacob Boysen i Gl. Haderslev og Peter Prahl i Vedsted, til at forfatte et lille folkeligt skrift med titlen Et Ord til Lægfolk. Forbilledet var en tysksproget pjece forfattet af pastor Ohlshausen i Oldesloe, og målet var at modvirke »fordomme og utilfredshed«. Pjecen var tiltænkt landbefolkningen, som skulle gøres begribeligt, at deres skepsis var ubegrundet. Biskoppen og amtmand Møsting i Haderslev var helt med på ideen, og i november 1797 fik hvert sogn i Haderslev Provsti pålæg om at indkøbe 50 eksemplarer af pjecen på kirkekassens regning og lade dem uddele gratis i deres sogne. 


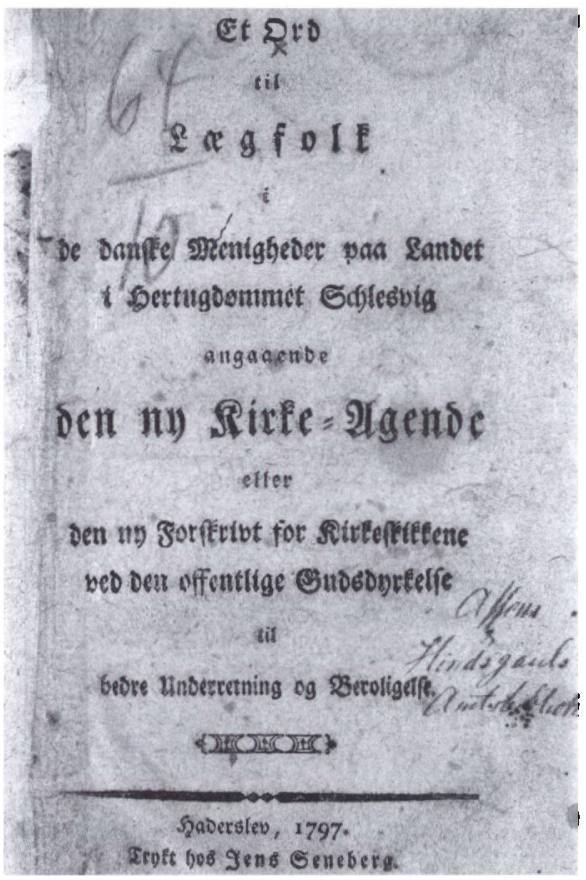

Pjecen Et Ord til Lægfolk (1797) var udarbejdet af sogneprasterne Prahl $i$ Vedsted og Boysen $i$ Gammel Haderslev. Den skulle påvirke sognefolkene til at tage godt mod den nye liturgi. Hvert sogn fik efter amtmand Mostings beslutning tilsendt 50 stk. til gratis uddeling. Men det gav bagslag. Bønderne var skeptiske og lagde mærke til, at pjecen ikke udtrykkeligt fremstod som kongens vilje. De opfattede pjecen som et privatinitiativ af præster, amtmand og proust og protesterede flere steder ved at levere pjecerne tilbage til præsten eller amtmanden.

\section{Uro i Nordfrisland}

Alt var således lagt til rette for, at den nye gudstjenesteordning kunne tages i brug ved nytår 1798. Men næppe var de første gudstjenester på den nye måde gennemført, før modstanden viste sig. Det begyndte på Sydslesvigs vestkyst. ${ }^{10}$ Folk påstod, at der var tale om »en ny religion«. I juli 1797 var Adler på visitats på Hallig Nordmarsch og fik en klage fra alle beboerne. De ønskede, at der ikke blev rørt ved dåb og nadver, skriftemål, evangelier, epistler og fadervor. Velsignelsen skulle fortsat forkyndes fra prædikestolen. Alle familiefædre i Witzwort og Ulvesbøl Sogne i Ejdersted klagede skriftligt over, at fadervor var forvansket, at indstiftelsesordene i nadveren var borte, at Kristus nu blot var lærer og ikke den, der gav frelse til evigt liv. De ville beholde Luthers katekismus. Luthers lære om retfærdiggørelse ved tro alene var trængt ud af kirken, påstod de. "Hvem er det som giver præsterne deres løn? Hvem giver dem husly? Er det ikke os i sognet? Så har vi vel også ret til at kræve, at præsterne ikke optræder som folkeforførere," skrev de selvbevidste Ejdersted-bønder. 
I Langenhorn udtalte menigheden sig ved visitatsen $\mathrm{i}$ juli mod agenden, og i oktober udtalte sognets officialer på vegne af 387 indbyggere, at der var meget anstødeligt i det ny ritual. I det lille Okholm Sogn ved kysten syd for Tønder sendte sognefolkene den 16 . november 1797 deres fire sogneforstandere til præsten for at kræve den rene Lutherlære genindført. Der blev brugt store ord: præsten forvanskede bibelen, forførte ungdommen, han var en falsk profet og løgner. Det var så grove sager, at amtmanden i Bredsted et par dage efter holdt forhør over de fire og fængslede den højtråbende ordfører. Det fandt Okholm-folkene sig ikke i. 50 mand stærk mødte op i Bredsted for at befri den fængslede. I selve Bredsted indsamlede de såkaldte tolvmænd (en slags sognebestyrelse) i juli 1797 stemmer om holdningen til agenden, amtmand Blücher idømte dem bøder, og de klagede til Tyske Kancelli. ${ }^{11}$

\section{Urorygter når Haderslev}

Rygter om de mange uroligheder nåede Haderslev-området i eftersommeren 1797. Meldingerne vakte "megen sensation blandt menigmand såvel i købstæderne som især på landet på grund af urigtige begreber om dens [agendens] indhold, " skrev pastor Boysen i Gl. Haderslev til amtmand Møsting 4. oktober 1797. ${ }^{12}$ I Tyrstrup Herred begyndte sognemændene at holde forsamlinger og tale om, hvordan de kunne hindre, at kirkeagenden blev indført. Særlig foruroligede det reformvennerne, at pastor Niels Mygind i Stepping-Frørup var kendt som afgjort modstander af nytænkningen. Siden 1777 var han sognenes afholdte præst, han var herrnhutisk sindet og modstander af reformen. Stepping-Frørup kunne udvikle sig til arnested for protest. Uddelingen af pjecen Et Ord til Lægfolk gjorde det ikke bedre. Folk var skeptiske, fordi skiftet ikke fremstod som en kongelig befaling, og de snakkede om, at der var tale om en forvanskning af den gammelkendte religion. Det var nok ikke kongen, men kun præsterne og amtmanden, som stod bag, mente de.

I Haderslev følte amtmand Møsting som statens overøvrighed ansvaret for, at nyordningen ville køre glat. I kirkevisitatoriet, den lokale kirkeledelse af amtmand og provst, var han den dominerende kraft, og han kunne slet ikke forstå, at lovgiveren havde valgt nærmest at smugle nyordningen ind ad bagdøren i stedet for at bekendtgøre den klart og tydeligt som kongelig befaling. Bønderne ville kun acceptere 


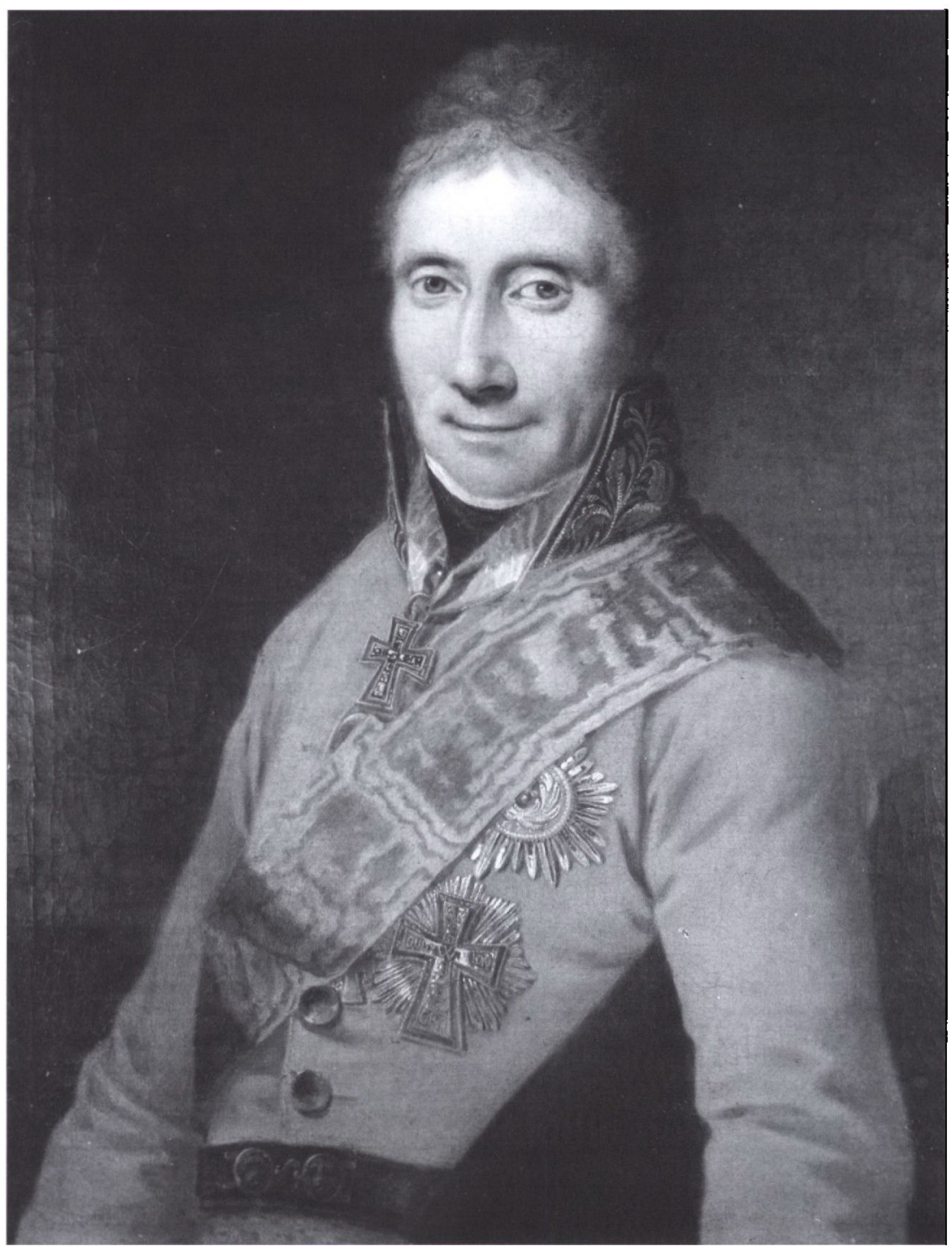

Johan Sigismund v. Møsting på højden af sin karriere, malet af C.A. Lorenzen $i 1815$, da han var blevet elefantridder og beklædte stillinger som finansminister og chef for Rentekammeret og medlem af Gehejmestatsrådet. Med stejl selvstændighed forsvarede Mosting $i$ disse år den bureaukratiske danske enevældes sag. Det samme kan man sige om hans optræden under liturgistriden $i$ Haderslev Amt 1797-98. Maleri i Altonaer Museum i Hamborg. 
ændringen, hvis den blev publiceret tydeligt og det som kongens udtrykkelige vilje. Da Møsting meddelte nyordningen til præsterne i et cirkulære af 30. oktober, gav han derfor lovgiverens ord en lille drejning. De skulle ganske vist foretage indførelsen uden postyr og forudgående bekendtgørelse eller anprisning fra prædikestolen, men kunne dog anprise det nye lejlighedsvist. Efter 1. januar 1798 skulle den fælles gudstjeneste foregå efter agendens forskrift. ${ }^{13}$ For en kongelig embedsmand som Møsting stod nyordningen ikke til drøftelse. Amtmanden betonede de ord i reskriptet, som talte om en fuldstændig og ubegrænset indførelse.

\section{Kancellichef Cay Reventlow spænder ben}

Man skulle have ventet, at centraladministrationen i København ville gøre alt for at lette arbejdet for den lokale administration. Men lige det modsatte skete. Indtil sommeren 1797 stod Tyske Kancelli bag reformen. Den 21. juni 1797 døde imidlertid Tyske Kancellis chef A.P. Bernstorff. Han havde været en af agendeprojektets støtter. Efterfølger på posten som leder af hertugdømmernes øverste centralmyndighed og dermed også kirkeforvaltningen blev svigersønnen Cay Reventlow. Han og hans kreds så skeptisk på oplysningstankerne. Broderen Fritz Reventlows gods Emkendorf i Holsten var samlingssted for alle modstandere af de moderne kirkelige strømninger. ${ }^{14}$ Emkendorf-folkene var hverken overraskede eller skuffede, da der fra sommeren 1797 kom protester mod den nye liturgi fra sogne i Holsten og fra Ejdersted-sognene Katharinenheerd, Witzwort, Ording, Osterhewer og Tetenbüll og fra Langenhorn og Bredsted på Sydslesvigs vestkyst. Det bekræftede deres modvilje. Reventlow tiltrådte embedet som chef for kancelliet 5. juli 1797, og dermed fik agendemodstanderne Tyske Kancelli som base. Reventlows tiltræden dannede skel i agendesagen. Bagefter opdelte Adler ligefrem sit arkiv i sager før og efter det famøse chefskifte. ${ }^{15}$

I en sag som angik folkets religion, kunne der ikke anvendes tvang, den ville kun fremkalde modstand, og man måtte hellere gå forsigtigt frem, mente Reventlow. ${ }^{16}$ Straks efter sin tiltræden lod han kancelliets førstemand, konferensråd Kristian Ludvig Schütz, udfærdige et reskript af 8. december 1797 til overkonsistorierne i Slesvig og Glückstadt, dvs. den øverste lokale kirkeforvaltning i hertugdømmerne. Mange præster, hed det i reskriptet, var gået for hurtigt frem; hvor 


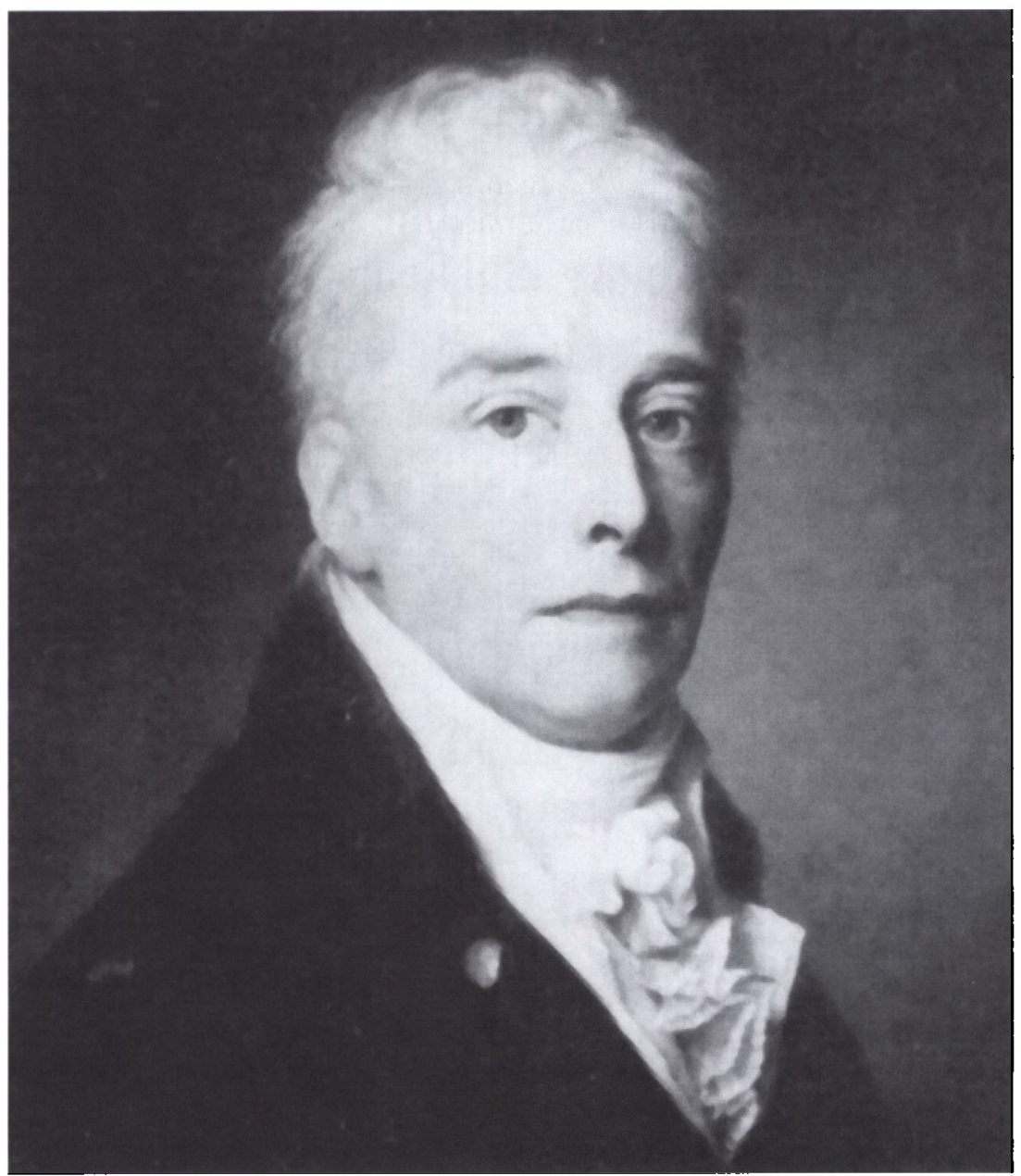

Cay Reventlow (1753-1834), chef for Tyske Kancelli 1797-1802. Ligesom broderen Fritz på godset Emkendorf var Cay modstander af tidens rationalisme. Hans tovende og uklare kurs over for menighedsprotesterne 1797-98 bxrer en stor del af ansvaret for, at den folkelige bevægelse greb om sig og fik et så overraskende forløb. Portræt af F. Gröger på Altenhof.

befolkningen viste modstand, skulle indførelsen af agenden derfor udsættes; præsterne blev forpligtet til at spørge de enkelte i menigheden, om de ønskede de gamle formularer anvendt ved dåb og vielse; de gamle tekster kunne om ønsket stadig oplæses. Det eneste, som blev fastholdt, var, at de nye foreskrevne tekster fra 1. januar 1798 
skulle danne grundlag for præsternes prædiken. ${ }^{17}$ Præsterne blev gjort ansvarlige for, at ro og orden blev opretholdt. Regeringen ville have ro og rådede til at vise lydhørhed over for befolkningens sindelag og modstand. Den faste tone fra kongen var afløst af uklare signaler.

De nye regler stod ikke i en egentlig forordning til alt folket, men var gemt $i$ et reskript til kirkeadministrationen. Rygtevis nåede de nye signaler dog hurtigt ud til folk, også i Haderslev-området. De forstod det sådan, at agenden helt var ophævet, og det virkede nærmest som benzin på en ulmende ild.

For de lokale embedsmænd, som havde fået til opdrag at gennemføre nyordningen, var dette højst problematisk. Adler undlod ikke at gøre sin højfornemme chef Cay Reventlow opmærksom på, at sogneprotesterne i hans øjne ikke var udtryk for religiøsitet, men for stivsind. Biskoppen frygtede, at regeringens mildhed ville blive tolket som svaghed og få de modvillige til at fremture, skrev han til Reventlow 27. december $1797 .^{18}$

I Haderslev talte Møsting langt mere uforblommet. Han fandt reskriptet "fatalt" og spurgte kritisk, om det mon var udsendt for bevidst at skabe anarki. Hvem kunne dog have forfattet noget sådant? "Aldrig havde jeg ventet at opleve en sådan angstfuld svaghed [fra regeringen] i roens land «, klagede han i et brev til generalsuperintendenten. Først overvejede han helt at henlægge reskriptet i sin skuffe. Men da dets ordlyd rygtedes ad uofficielle kanaler, og bønderne opfattede det som udtryk for, at agenden var ophævet, måtte han gå mere offensivt til værks. Den 12. januar 1798 udgik derfor fra amtshuset et cirkulære til præsterne, hvor Møsting meddelte december-reskriptet på sin egen måde. Hvor agenden allerede var taget $i$ anvendelse, var der ingen vej tilbage, her skulle reskriptet ikke gælde og agenden stå ved magt, skrev han til sine præster. Han var sig bevidst, at han her gav det kongelige reskript en drejning, men det ville han tage med - for det gjaldt om at redde agenden. ${ }^{19}$

\section{Jels Sogn protesterer}

Alt imens var uroen i fremmarch. Befolkningen tog den dulgte lancering af nyordningen som udtryk for, at det nok var præsternes påfund, og de valgte at protestere. Det begyndte i Jels i Gram Herred. Her havde sognepræsten, den oplysningsbegejstrede Johannes Bjørnsen, Møstings og Adlers meningsfælle ${ }^{20}$, taget nyordningen i brug 
straks 1. januar. Men så kom rygtet, at agenden var ophævet. Sognemændene holdt møder, og den 10. januar afleverede to deputerede fra landsbyen Grønnebæk et bønskrift til præsten med 39 underskrifter mod agenden. Den 13. januar færdiggjorde også Jels-folkene en skrivelse underskrevet af 18 »og mange flere som ikke ere antegnede«. De bad om at måtte beholde den gamle kirkeskik. Pastor Bjørnsen reagerede afvisende, for her prøvede folk i menigheden at gøre sig til herre over deres præst. I Bjørnsens øjne var der tale om overtroiske folk, om en enfoldig og ondskabsfuld koalition af »tomme, formørkede og stive hoveder, som var mod alt nyt « og som var vakt af rygterne sydfra og af snak om, at pastor Mygind i Stepping offentligt havde talt mod nyordningen. Ophavsmændene i Jels var i præstens øjne »de mest elendige og dårlige fyre som Nis Dam, Mads Skomager, Mathias Holt eller Urmager «. I Grønnebæk "skal to trættekære kvinder på ondskabsfuld måde næsten have tvunget hele hoben af enfoldighedssmørere til at bombardere mig, « klagede Bjørnsen til amtmanden.

Møsting gav straks reformpræsten sin fulde opbakning. Han og hans kolleger skulle ikke lade sig afskrække, om nødvendigt ville han selv komme ud "og afgøre sagen med den forsamlede menighed «, skrev han tilbage. Til Jels udfærdigede han et brev på dansk, »for at enhver desto bedre kunne forstå samme«. Det var Møsting ukært, skrev han, at erfare bylaugets genstridige fremfærd. Kun folk, der var ufornuftige eller enfoldige eller med slette hensigter, kunne være mod det nye. Amtmanden gentog, at den almindelige gudstjeneste og prædiken skulle følge agenden og de nyforeskrevne tekster. Dog kunne den enkelte vælge de gamle formularer til de kirkehandlinger, som angik ham personligt. ${ }^{21}$

Brevet skulle forelægges de forsamlede sognefolk, og mødet blev henlagt til den loyale sognefoged Jep Jessen hus af frygt for, at et møde i værtshuset skulle føre til "uorden og grovhed". Men ved mødetidspunktet den 30. januar kl. 6 var stuen hos sognefogeden næsten tom, »de urolige « havde samlet sig i værtshuset for at planlægge en henvendelse til kongen. Efter nogen tid lykkedes det at få »det stivsindede pak « (starrköpfige Gesindel) til at komme, og præsten oplæste amtmandens budskab. Han forsøgte at overbevise om det fortrinlige i det nye, og det fik nogle til at udtale, at de vist hellere måtte opgive tanken om at indsende ansøgninger mod nyordningen.

Sådan gik det dog ikke. "Komplottet « forlod nemlig sognefogedens hus noget før de øvrige og gik hen til værtshuset for at drøfte videre. 
Her blev besluttet at se tiden an. Der var nemlig netop indløbet rygte om, at sognefogederne i Tyrstrup Herred havde en større protestaktion under forberedelse. Det var nok klogt at afvente udviklingen dér. ${ }^{22}$

\section{Det herrnhutiske Stepping-Frørup}

Her skifter scenen til Tyrstrup Herred. Stepping-Frørup med den uforfærdede agende-modstander Niels Mygind blev arnestedet for videre protest. Her var den ny liturgi højst $i$ brug de første tre søndage efter nytår. Så forsamlede de to sogne sig og bad om, at den gamle kirkeskik blev genindført. Rygtet om, at agenden skulle være ophævet, har sikkert medvirket. I alt fald blev 30-35 af de udleverede pjecer Et Ord til Lægfolk leveret retur fra menigheden, og et par sognemænd tog ind til provsten $\mathrm{i}$ Haderslev for at bede om at blive forskånet for agenden. Selv opsøgte Mygind den 24. januar provst Strodtmann og oplyste, at alle i sognet var mod agenden, og han fralagde sig ethvert ansvar for dens indførelse.

Da Møsting blev orienteret, reagerede han med det helt skarpe skyts mod præsten. Det gjaldt om at standse den genstridige, ellers kunne han sætte en kædereaktion i gang. Den 26. januar sendte amtmanden derfor en bandbulle til Stepping-præsten: "Sognet er enigt om ikke at ville det, som kongen vil. ... Det er en sammenrotning, som De, Pastor Mygind, står i spidsen for!« Præsten svigtede den lovlydighed, som det herrnhutiske Christiansfeld ellers var kendt for. Kongens befaling var, påstod Møsting, at gudstjenesten som helhed skulle indrettes efter agenden; friheden gjaldt kun den enkeltes valg af formularer og evt. oplæsning af de gammelkendte tekster. »Kan jeg ikke udrette noget med det gode, så vil jeg vide at bringe kongens vilje til udførelse med tvang og på passende måde at tugte genstridigheden mod øvrighedsbefalinger, " advarede Møsting. Parerede præsten ikke ordre, skulle han førstkommende mandag indfinde sig hos Møsting og forklare sig. ${ }^{23}$ I første omgang fik Møsting sin vilje. Mygind bøjede sig og benyttede de følgende tre eller fire søndage den nye liturgi ved gudstjenesterne. ${ }^{24}$

\section{Kongen tillader protestafstemninger}

Ved udgangen af januar var reformen allerede på manges læber. Da kom endnu et udspil fra København, som satte yderligere gang i pro- 


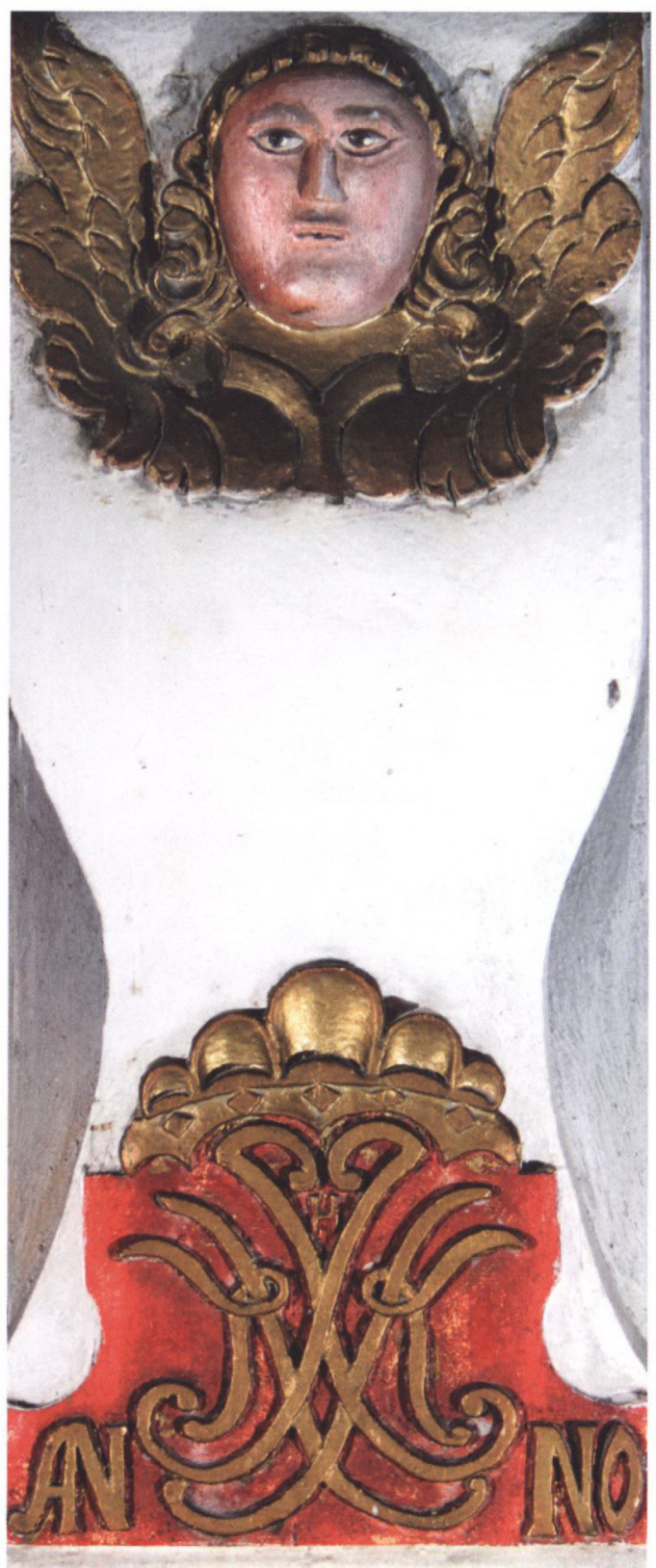

I 1752 fik Frorup kirke en ny altertavle skåret af den lokale snedker Jochum Nielsen. Midterbilledet flankeres af to flade søiler (pilastre), som begge nederst har et fremstaende fodstykke (postament) med et englehoved overst og et spejlmonogram nederst. Spejlmonogrammet her viser bogstaverne H I K for hr. Jorgen Kastrup, sognepræst $i$ Stepping-Frorup 1738-77. Kastrup var pietist af herrnhutisk indstilling. I hans tid blev der indrettet en modesal $i$ præstegården, og pastoratet blev et slags center for herrnhutisk arbejde $i$ Nordslesvig. I 1770 fik Kastrup en ligesindet hjælper, da Niels Mygind blev udnæont til adjunkt. Kirkeinteressen var stor $i$ Stepping-Frarup menigheder $i$ det meste af 1700-tallet. Kastrup tiltrådte embedet efter, at en deputation fra sognet havde taget den lange rejse til Kobenhavn for at give ham en varm anbefaling. Hændelserne under agendestriden $i$ 1798 var således varslet af en levende kirkelig interesse $i$ de foregaiende år. Foto: Martin Bo Norregdrd. 
cessen. Kancellichef Cay Reventlow var foruroliget over den voksende uro og var utilfreds med de præster, som var gået for hurtigt frem. Derfor lod han den 26. januar udsende endnu et regelsæt. Målet var at berolige gemytterne, og denne gang var der tale om et patent, altså et kongeligt åbent brev beregnet til oplæsning fra prædikestolene. ${ }^{25}$ Patentet var en æggedans. På den ene side blev fastslået, at agenden var udtryk for sand evangelisk kristendom: Nyordningen indeholdt intet andet end Jesu hellige religion, og kongen forsikrede menigheder, som benyttede den nye orden, om sin velvilje og støtte. På den anden side var der tale om en samvittighedssag, og regeringen ønskede ikke at lægge nogen under tvang. Ønskede en menighed at fastholde den hidtidige gudstjenesteform, var det derfor muligt. Der kunne holdes afstemning for og imod det nye. Ønskede kun en del af husfædrene at fastholde det gamle, kunne der veksles mellem gammel og ny liturgi. Hvis nogen misbrugte friheden og optrådte »opviglende « eller tillod sig noget upassende mod præsten eller forstyrrede den offentlige gudstjeneste, ville det blive straffet strengt med indsættelse i nærmeste fæstning.

To uger efter udsendtes endnu et reskript, som imødekom kritikerne: Fadervor skulle bedes "med Kristi ord", og den mosaiske velsignelse kunne fortsat benyttes, hvor menigheden onskede det. ${ }^{26}$ Generelt skulle der råde samvittighedsfrihed, tvang skulle ikke anvendes i spørgsmål om religion. Kongen lagde nærmest afgørelserne ud til befolkningen for at få ro.

Det overraskende tilbagetog var som et slag ansigtet på vore to hovedaktører. Adler var dybt utilfreds med den eftergivenhed, der lå $i$ at prisgive de nye tekster og tillade afstemningerne. ${ }^{27}$ Møsting sagde det endnu mere tydeligt. Ubarmhjertigt afklædte han lovgiverens "elendige angst «:

"Oh, gid dog Himlen ville forbarme sig over dette makværk, som aldrig burde have haft plads mellem landets forordninger. I begyndelsen af dette pyntelige patent optræder landsherren som moralist, i midten overfaldes han af angst, til sidst bliver han så vred, at han først ønsker straffe, så undersøgelser. Her kan man dog sige med al ret: Oh, gid dog himlen vil forbarme sig over dette makværk [Unding] af et patent. Denne ene bestemmelse er tilstrækkelig til at berøve lovene den nødvendige agtelse og de udførende embedsmand al deres autoritet. Patentet lægger grunden til et anarki, som måske ikke kan afhjælpes i et halvt århundrede, det slår døren op på vid gab for 


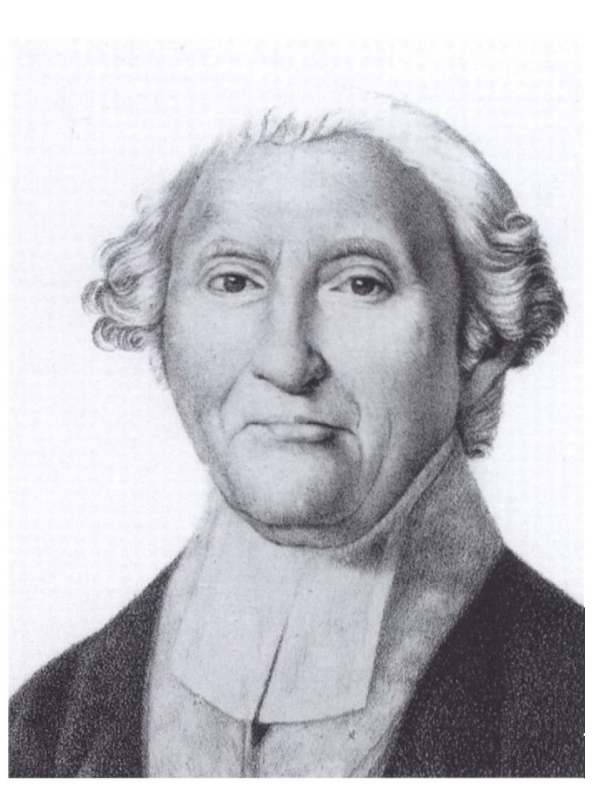

Jacob Georg Christian Adler (17561834), generalsuperintendent for Slesvig fra 1792 til 1834 og fra 1806 samtidig for Holsten. Litografi af $M$. Mendel, 1828. Foto: Arkivet ved Dansk Centralbibliotek for Sydslesvig.

urostiftere. Min kære Ven! Rescriptet var slemt, men patentet 10 gange værre. Jeg er fast besluttet på ikke at publicere det her. Kommer der klage derover, så vil jeg sige, at jeg har forstået det sådan, at det kun er møntet på de steder, hvor agenden ikke har kunnet indføres, og at en publicering her, hvor alt går sin gang, kun ville have skabt uro. Får jeg en tilrettevisning, så vil jeg sluge den pille," skrev han til Adler. ${ }^{28}$ Borgmesteren i Haderslev by, Niels Sørensen, var på samme linje og skrev til Møsting: "Jo mere jeg tænker over det nye patent, jo mere uforklarligt bliver det mig, hvordan man har kunnet gøre noget, som er så uhensigtsmæssigt og inkonsekvent. ${ }^{29}$ Helt oppe i statsrådet var kronprinsens svoger, hertug Frederik Christian af Augustenborg, på samme hold. Anslaget mod den nye kirkeorden var et udtryk for ortodoksi og for ængstelighedens og vankelmodets onde ånd, skrev han til sin søster. ${ }^{30}$

De kongelige embedsmænd, Møsting og borgmesteren, følte sig svigtet. I deres øjne manglede de nye kongelige forordninger totalt klarhed og konsekvens. Hvordan kunne de bevare en ophøjet autoritet over for befolkningen under sådanne betingelser? Uofficielt enedes biskop og amtmand om at tolke patentet og dets ord om adgang til afstemning sådan, at det kun gjaldt, hvor der havde vist sig uro. Hvor 
agenden allerede var indført, kunne der ikke være nogen vej tilbage, og her kunne afstemninger ikke komme på tale. Der skulle ikke være nogen fortrydelsesret. ${ }^{31}$ Amtmand og generalsuperintendent stod sammen om en stille omgåelse af statsledelsens bestemmelser.

\section{Genstridige sognefogeder}

Da "afstemningspatentet« blev kendt, kom protestvognen for alvor op i fart. Sidst i januar $1798 \mathrm{blev}$ pastor Petersen i Fjelstrup opsøgt af repræsentanter fra byerne Fjelstrup og Sillerup, som bad om, at han bevarede den gamle kirkeskik. ${ }^{32}$ Præsten fik dem snakket fra det, men kort efter gik herredets sognefogeder i fælles aktion. Den 8. februar, gentaget den 13. februar, blev patentet offentliggjort i avisen Altonaischer Mercur og læst af de mest fremmelige blandt bønderne. Folk forstod det sådan, at regeringen ikke ville anvende tvang, at den respekterede samvittighedsfriheden, og at sognene kunne tilkendegive deres mening ved at holde afstemning. Kongen var på menighedernes side mod amtmanden inde i Haderslev!

Avisbekendtgørelsen gav de utilfredse rygstød. Den 4. februar havde Jørgen Roy i Knud, sognefoged for Fjelstrup Sogn, udsendt en cirkulæreskrivelse ${ }^{33}$ til sine kolleger i Tyrstrup Sønder Herred, dvs. i Bjerning, Tyrstrup, Hjerndrup, Stepping og Frørup Sogne: »Vores Sogns Interessenter har adskillig bedet mig at tale med andre Sognefogder i Herredet om Religionens nye Forfatninger, hvorledes samme for nærværende og i den tilkommende Tiid kunde ansees, eller om et Forsøg til Kongen imod dette paa den beste Maade skulle anvendes. Jeg talte forleden Dag med nogle Sognefogder i Nør Herredet, som ønskede det samme, Peter Iwersen i Weistruproy circulerer til de øvrige Sognefogder i Herredet." Skrivelsen indkaldte til at møde i værtshuset i Christiansfeld lørdag den 17. februar kl. 10 for solidarisk at drøfte sagen. Hver sognefoged skulle forinden gøre sig bekendt med, hvorledes hans sognefæller "med det nærværende er fornoyet; for det øvrige ombedes enhver dette circulair og denne Samling at holde hemmelig. « Kollegaen Peter Iversen i Vejstrup indkaldte tilsvarende sognefogederne i Ødis, Vonsild, Bjert, Dalby, Stenderup, Hejls, Taps og Aller. ${ }^{34}$

Hemmeligheden holdt ikke. I Ødis fik degnen nys om papiret, skaffede sig en afskrift og gik til sin sognepræst, M.G. Chemnitz. Foruroliget lod han lørdag den 9. februar papiret gå med ilbud til amtman- 


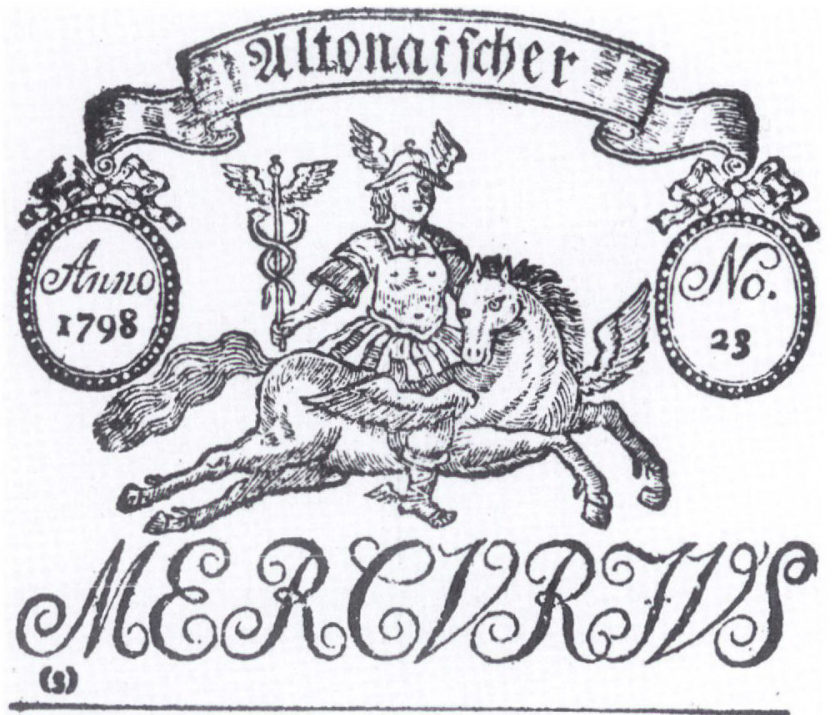

\section{Donnerftag, ben 8 gebruar.}

zopenbagen, vom 3 gebruar.

Cin ou Der Sibuigl. Dentfoen sanjlev unterm $26 \mathrm{ften}$ Shs

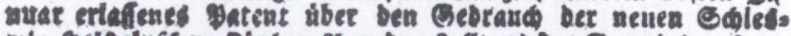
vis folRetuiden sirden: Ogenbe, ftell es ven Semetuben fret.

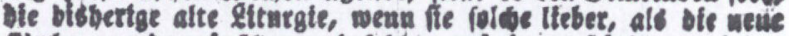

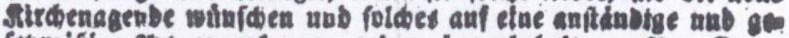
febmafige firt st extennen geben, besgubebalten. \$20 Eopt:

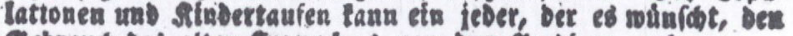
Cebraud Des alten formular vou bem Orebiger verlangen.

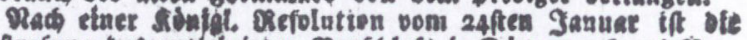

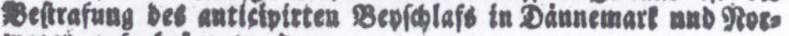

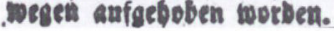

Den 8. februar 1798 blev et uddrag af 26. januar-patentet bekendtgjort i bladet Altonaischer Mercurius. Det korte uddrag fremhævede, at menighederne nu havde frihed til at vælge mellem gammel og ny liturgi, blot de fremkom med deres onsker på en anstændig og lovmassig made. Stik mod lovgiverens onske pustede denne udmelding imidlertid sådan til uroen, at det blev fundet nødvendigt at gengive patentet $i$ fuld udstrækning $i$ bladets udgave fra 13. februar. En sådan gentagelse var ganske usædvanlig.

den. Præsten bad om, at hans rolle som meddeler ikke blev røbet, »idet denne sag ellers let vil kunne give mig mange ubehageligheder".

I amtshuset følte Møsting sig alvorligt udfordret på sin autoritet. Sognefogedernes embedsed foreskrev, at de skulle være deres arvekonge tro, vise lydighed over for amtmanden som deres foresatte, 


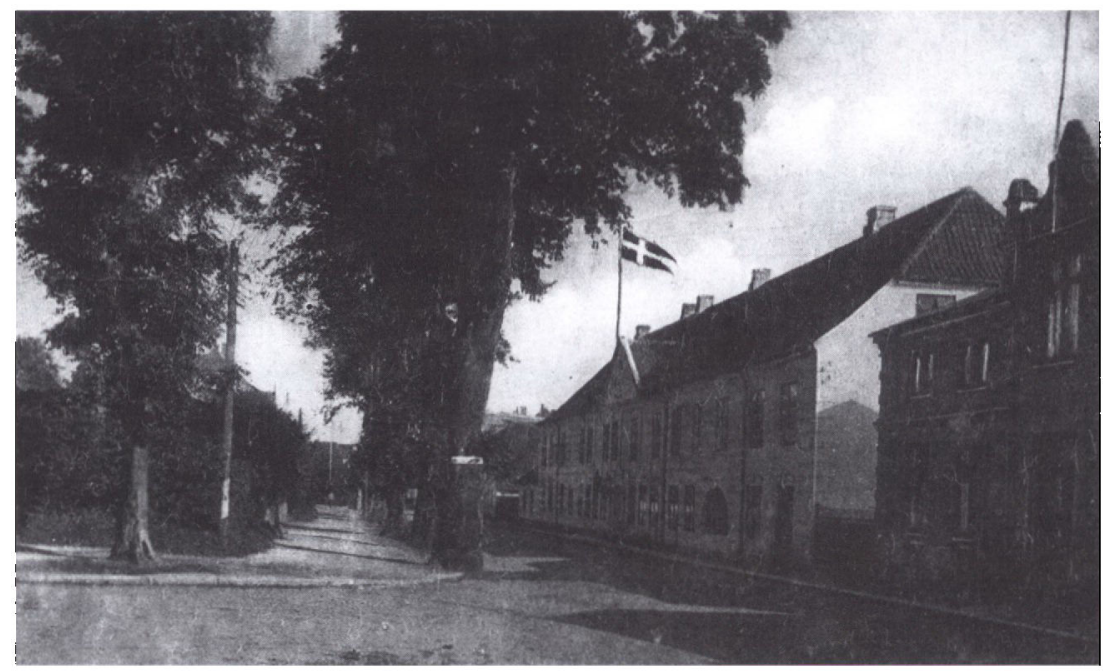

Haderslev Stiftamt, Møstings residens i amtmandsårene 1789-1804. Husets herre var en meget selvstændig embedsmand. I amtshuset gennemfortes de mange forhor med utilfredse amtsbeboere under liturgistriden. Provst Strodtmann blev stort set holdt udenfor. Enten blev han slet ikke inddraget, eller han fik blot en sag forelagt til konmentarløs underskrift. Det klagede han over i 1802 - og generalsuperintendenten gav ham ret. Foto omkring 1920 i Museum Sonderjylland-ISL-Lokalhistorie.

straks udføre ordrer fra amtets betjente, sørge for at forordninger blev bekendtgjort og indberette alt, som stred derimod til amtet, kort sagt fremme kongens og undersåtternes bedste. ${ }^{35}$ Det havde sognefogederne handlet imod, mente Møsting, og ufortøvet sendte han ilbud til samtlige 15 sognefogeder: Det originale circulære-brev skulle straks indsendes til ham "med en Expres", og de to initiativtagere blev stævnet til at møde på amtshuset den følgende dag, søndag den 10 . februar.

Straks de ankom til amtshuset blev de to gårdmænd suspenderet fra deres embeder, og Møsting gav husfoged Peter Brekling ordre om at udnævne midlertidige sognefogeder $\mathrm{i}$ deres sted. Det blev gårdejer Erik Hansen i Grønninghoved i stedet for Peter Iversen, og Søren Madsen i Knud i stedet for Jørgen Roy. ${ }^{36} \mathrm{Om}$ mandagen fik samtlige Tyrstrup Herreds sognefogeder brev fra amtmanden, at de to kolleger var suspenderede, at det planlagte møde og alle lignende møder var ulovlige, og de blev kraftigt bebrejdet, at de ikke havde robet planen. Ethvert lignende møde skulle de forhindre. Møsting henviste til et patent af 11. september 1795, som forbød al sammenløben og »opvig- 
len «, for hvilket der var fastsat streng straf. ${ }^{37}$ For en sikkerheds skyld udgik også cirkulære til Haderslev og Gram Herreder, som blev advaret mod at afholde nogen form for forsamlinger vedr. kirkeagenden.

Peter Iversen og Jørgen Roy affandt sig ikke med suspensionen. Inden søndag den 10. februar var til ende, havde de udformet en klageskrivelse til Tyske Kancelli i København. De forklarede, hvordan sognefolkene forud havde bedt dem om at indkalde til forsamlinger for at få kirkeordningen standset. De havde indkaldt til mødet, men det var sket for at tale sagen til ro, påstod de. Brevet afgik sammen med et andragende undertegnet af 77 sogneboere fra Fjelstrup menighed til kancelliet om at blive fri for agenden. "Som vi kan læse af Aviserne saa skal dette også være Deres Kgl. Majestæts Vilje, « sluttede anmodningen håbefuldt. ${ }^{38}$ Pastor Prætorius i Vejstrup kunne fortælle, at Peter Iversen holdt en forsamling i sit hus dagen efter afsættelsen. ${ }^{39}$

\section{Amtmand i kamp for sin autoritet}

Heller ikke Møsting forholdt sig i ro. Han indberettede episoden til sin umiddelbare overordnede, Overretten i Slesvig, og bad om, at suspensionen af de to sognefogeder blev stadfæstet, at de blev afskediget og blev idømt fire ugers fæstnings- eller fængselsstraf. Men i Overretten rådede nu den milde kurs, som senest var kommet til udtryk i patentet af 26 . januar. Overretten vurderede, at sognefogederne havde handlet ud af »misforstået religiøsitet, vrange forestillinger og forstandsfejl $\ll$. Der kunne ikke fares hårdt frem, og man underkendte suspensionen. Amtmanden skulle kun tildele de to sognefogeder en irettesættelse, men i øvrigt lade dem fortsætte i deres embeder. ${ }^{40}$

Den kongelige amtmand blev oprørt, "men så let lader jeg mig ikke affærdige«, skrev han til Adler. ${ }^{41}$ Foreløbig undlod han at bringe afgørelsen videre til amtets befolkning og valgte at tale sine overordnede imod. Sagen var intrikat, for reelt havde Tyske Kancelli nu næsten taget afstand fra agenden. Møsting var derfor nødt til at belægge sine ord og nedtone agende-aspektet. Han skrev til Overretten og Tyske Kancelli i København og redegjorde for, at sagen drejede sig om hans autoritet som amtmand. Mødeindkaldelsen var et åbent brud på det førnævite patent fra 1795, som forbød uautoriserede sogneforsamlinger. Der var tale om en kim til opstand og tumult, om ulovlig indblanden $i$ andre sognes anliggender, om udbredelse af »oprørsånd 
ved den påtænkte fællesforbindelse af et helt herred for at nå et mål«. Der måtte råde gensidig tillid mellem amtmand og sognefogeder, skrev han i sin indsigelse. Som amtmand måtte han kunne forlade sig på sognefogederne, og de skulle være afhængige af ham. Overrettens benådning af de to ville få sognefogederne til at vise foragt og ligegyldighed over for amtmandens befalinger, og undersåtterne ville i stedet vise slavisk frygt over for sognefogederne som almægtige væsener. "Når man ved, hvor lidt en irettesættelse virker på bønder, så vil man forstå, at disse bondefogeder vil tage let på den irettesættelse, jeg skal give dem. I skænkestuer og bondeforsamlinger vil de triumfere over, at suspensionen er ophævet, og de vil give udtryk for, at deres hele optræden har mødt betydeligt bifald, og det vil ødelægge min indflydelse på mine forretninger og indbyggerne. Det kan især ventes af sognefoged Peter Iversen, som er kendt som en slet, men også en så snu mand, at man meget sjældent kan overbevise ham om hans slette streger.« Sine foresattes afgørelse kunne Møsting ikke ændre, men i det mindste ønskede han at måtte blive forskånet for enhver kontakt med de to formastelige. Han bad Tyske Kancelli om, at den ønskede 'afskedigelse' blev effektueret i form af 'fritagelse for embedet'. ${ }^{42}$

I privatbreve søgte Møsting at påvirke først sin umiddelbare foresatte, chefen for Overretten i Slesvig, kansler Friedrich von Bardenfleth, og derefter den allerhøjeste chef, direktøren for Tyske Kancelli, statsminister og greve Cay Reventlow. ${ }^{43}$ Amtmanden kunne simpelthen ikke leve med den kompromittering, som lå i genindsættelse af sognefogederne.

Den besværlige sag blev drøftet intensivt $\mathrm{i}$ både Overretten i Slesvig og Tyske Kancelli i København. Her endte kollegiet med at konkludere, at det trods alt ville være uheldigt at vise for stor eftergivenhed. Møsting blev støttet $i$, at de to sognefogeder havde været forpligtet til at forhindre og anmelde offentlige forsamlinger, som kunne skabe uro og tumultariske sammenløb og egentlig var hjemfaldne til afskedigelse på gråt papir og fængselsstraf. Men man valgte et kompromis. Suspensionen blev godkendt, men sognefogederne skulle ikke "afskediges « og straffes, som de havde fortjent, derimod blot afgå fra embedet. For at styrke Møstings position skulle afgørelsen formuleres sådan, at formildelsen skyldtes Møstings eget forslag! I sandhed en salomonisk afgørelse. Christian 7. gav sin underskrift, og afgørelsen blev kundgjort ved reskript af 31 . maj. ${ }^{44}$ 


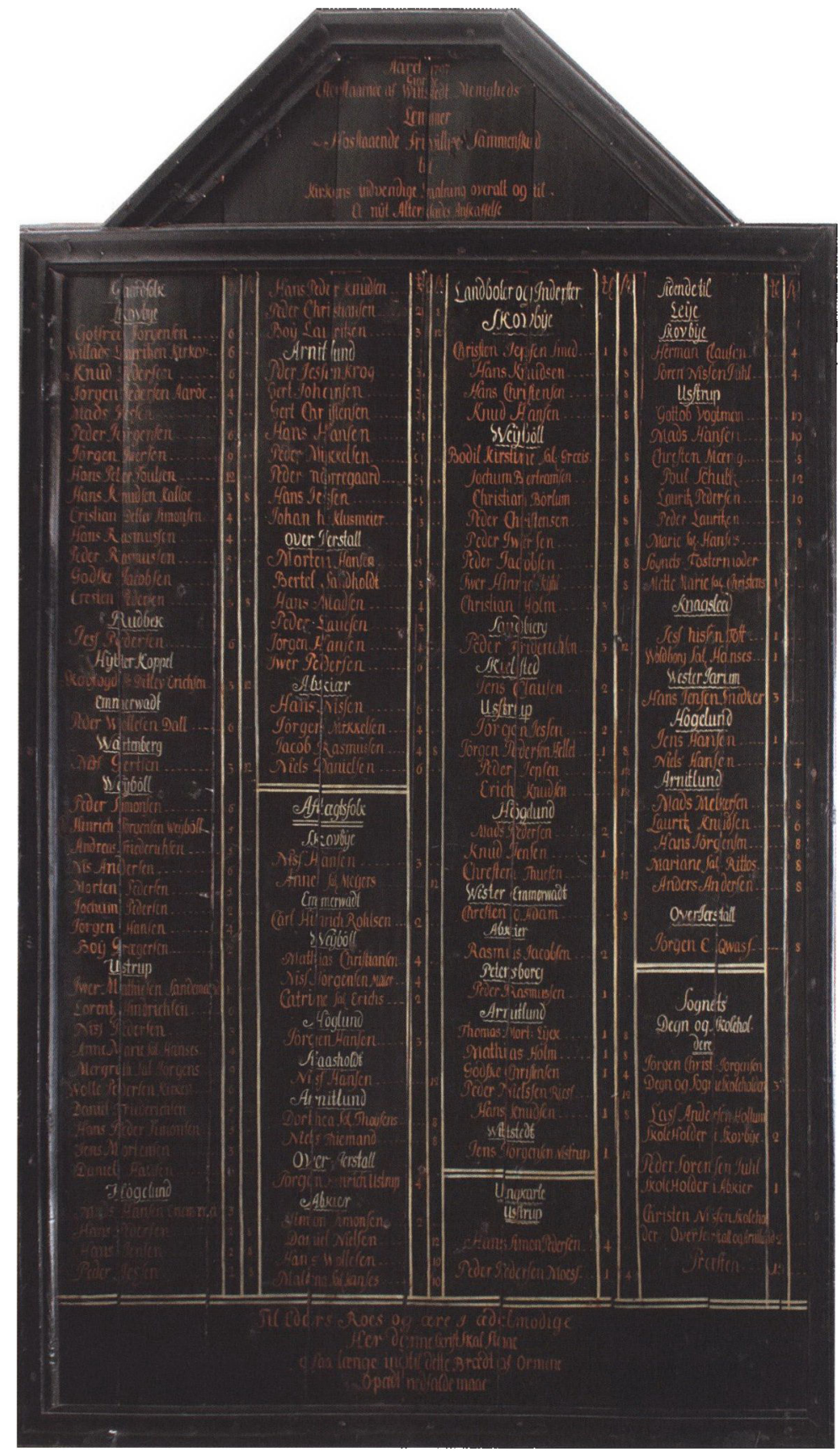


Det er ikke svært at forestille sig Møstings ansigtsudtryk. Den 11. juni stod Peter Iversen og Jørgen Roy skoleret på amtskontoret og påhørte kongens resolution: Den lovstridige mødeindkaldelse havde fortjent en regulær afskedigelse (Entsetzung) og en passende fængselsstraf. Men alene på grund af amtets/Møstings ansøgning blev de benådet til kun at blive fritaget fra embedet (Dienstentlassung) og befriet for den fortjente fængselsstraf. Sagsomkostningerne skulle de betale. ${ }^{45}$

Det tog nu ikke modet fra de afskedigede, de havde stadig opbakning i deres sogne. I Vejstrup førte Peter Iversen pennen, da 72 sogneboere 5 . maj undertegnede en ansøgning om at beholde den gamle agende. I Fjelstrup indgav menigheden fornyede ansøgninger den 21. maj og 9. september, den sidste med 108 navne. Den afskedigede sognefoged spillede sikkert en rolle her. I alt fald søgte sognepræsten Daniel Petersen bort fra sognet med den begrundelse, at han "på grund af en sognefogeds afskedigelse har måttet tåle mange ubehageligheder«. I 1800 blev han præst i Bov. ${ }^{46}$

\section{Kaotisk afstemningsbølge}

Møstings delvise sejr over de to sognefogeder hindrede ikke, at konfrontationen gik videre. Stepping-eksemplet og 26. januar-afstemningspatentet gav bønderne blod på tanden. Sogn efter sogn formulerede indsigelser mod det nye.

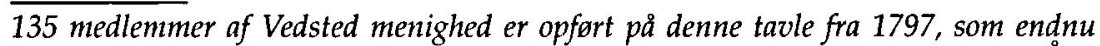
hanger $i$ kirken. Den er minde om deres bidrag til en nymaling af kirkens indre. Aret efter var en lang række af de samme mennesker at finde blandt de 69 fra sognet, som egenhændigt undertegnede en protest mod den nye kirkeliturgi. Aftagtsmand Iver Pedersen fra Over Jerstal, som agiterede mod agenden $i$ februar 1798 og sorgede for afsendelse af andragenderne til København $i$ april og juni, ses $i$ anden kolonne $p \stackrel{2}{ }$ tavlen sidst under Over Jerstal. Ottemand og smed Gert Johansen, som i marts 1798 siges at være hovedmanden $i$ protesten, ses $i$ anden kolonne som nr. 2 under Arnitlund. Skrædder Christian Rasmussen Borlum i Vejbol, som personligt rejste til Kabenhavn i november 1798 med klagerne fra Vedsted og Hammelev, ses $i$ tredje kolonne under Vejbøl. Øverst og nederst pơ tavlen lases: "Aaret 1797 giorde Efterstaaende af Wittstedt Menigheds Lemmer hosstaaende frivillige Sammenskud til Kirkens indvendige Malning overalt og til et nyt Alterklædes Anskaffelse«...

"Til Eders Roes og Ere I ædelmodige

Her denne Skrift skal staae

Saa lange indtil dette Brædt aaf Orme

Opxdt nedfalde maae."

Foto: Martin Bo Norregård. 
Pastor Peter Prahl i Vedsted Sogn var nok den mest fremtrædende af alle agendevennerne. Han var ikke bare forfatter af oplysningspjecen Et Ord til Lægfolk. Året efter udgav han to småskrifter om kritiserede punkter i reformen, Morten Luther: Omdømme og Betænkninger over sømmelige Forbedringer $i$ Kirkeskikkene, samlede og oversatte for Almuen, og ledsagede med nogle Anmærkninger, samt En kort og sandfardig Historie om Bondemanden Kristen Jensen Ehregott, om hans Maade at bede paa og især om hvorledes han bad sit Fader Vor. Sammenskrevet til Eksempel og Opmuntring for dem, der onske at kunne bede paa en forstandig, Gud behagelig og dem selv og Andre nyttig Maade. ${ }^{47}$. Pastor Prahl ønskede den bredest mulige anvendelse af den nye liturgi, men det var hans menighed ikke enig i. Aftægtsmand Iver Pedersen fra Over Jerstal førte ordet. Den 10. februar samlede han en del af helligdagsfogederne i Slukefter kro, og da mange fra sognet var i Haderslev fastelavnsmandag den 19. februar, havde han også fat i mange dér. En sandemand fra sognet opsøgte Møsting, men amtmanden gjorde, hvad han kunne for at få ham fra modstanden. ${ }^{48}$

I Oksenvad holdt befolkningen møde mod agenden i degnehuset den 24. februar. Skrædder Christopher Nielsen Timm fra Mølby, som havde været aktiv allerede i Jels-uroen i januar, påstod, at de små oplysningsskrifter om agenden var »fabelbøger«, som man ikke kunne lære noget godt af. Da pastor Bjørnsen tilfældigt tiltalte ham med »du“, replicerede skrædderen, at det skulle præsten ikke gøre, for de havde ikke passet svin sammen, og Timm havde lige så megen ret til at tiltale præsten med du. Han udlod sig med masser af ytringer mod øvrigheden og betvivlede, at kongen ville have agenden indfort. Det var noget, præsterne havde fundet på. Øvrigheden behøvede man ikke frygte, den ville gøre, som folk ville, og havde ikke mod til at gøre alvor af sine trusler. »Hvordan skal vi præster holde den trodsige og egensindige pøbel inden dens skranker? « sluttede pastor Bjørnsen sin indberetning til Møsting om mødet. ${ }^{49}$

Det lugtede næsten af oprør. Møsting stævnede Timm til forhør i amtshuset og idømte ham en bøde på $10 \mathrm{rdl}$. for at have drevet skrædderi uden koncession og forbød ham håndteringen fremover. Det bragte den fattige mand i så stor nød, at sognepræsten syntes, han var nødt til at gå i forbøn for ham. ${ }^{50}$ Til påske og pinse beskar »bandeførerne" $i$ Jels Sogn præstens offer til næsten en tredjedel. ${ }^{51}$

Maugstrup og Sommersted Sogne var de næste i rækken af protestanter. I Sommersted blev pjecen Et Ord til Lægfolk uddelt, og agen- 
den taget i brug 1. januar. Men efter 4-5 søndage var modstanden vakt. En lørdag eftermiddag samledes menigheden i skolehuset, tilkaldte den oplysningsvenlige pastor Roloffsen og bad om at blive fri for den nye liturgi. De uddelte eksemplarer af Et Ord til Lægfolk blev leveret tilbage med ordene: "Dér har De det letsindige og syndige skrift, som aldrig mere skal læses eller lægges på hjerte hverken af gamle eller unge," og samtidig blev der talt om, at man ønskede sig en Guds mand som pastor Mygind i Stepping som præst. Roloffsen prøvede at berolige og forklare fornyelserne. ${ }^{52}$ Den 12 . februar 1798 ansøgte Sommersted-folkene sammen med menigheden i Maugstrup amtmand og provst om at overtale deres to sognepræster til at vende tilbage til gammel skik. Ønsket »er ikke vor allernådigste konges landets faderlige vilje imod «, anforte de og tilføjede, at de ved et nej "ellers se os nødtvungne at søge højere steder, da vi uden de hårdeste tvangsmidler ikke underkaster os den nye. ${ }^{53}$

Det bragte øjeblikkeligt Møsting i affekt: Ansøgningen viste, at folk fra to sogne, som ikke udgjorde ét pastorat, havde stukket hovederne sammen, og det var ulovligt ifølge oprørspatentet fra 1795, ganske uanset agendereskripternes ord om hensyntagen til folks samvittighed og ret til at ytre sig ved afstemning. Tilmed robede ordvalget, at ansøgningen var ført i pennen af en uden for sognet. Møsting opsporede, at det var en gæstgiver Hans Bertelsen i Haderslev, og bad straks magistraten forhøre Bertelsen om ophavsmændene.

Sommersted-boerne enedes nu om en separat henvendelse. Den 16. februar blev der samlet 90 underskrifter for den gamle agende på en ny ansøgning. Møsting indkaldte nogle af folkene til forhør. De lagde ikke skjul på deres syn på amtet: Peter Lauritzen fra Sommersted sagde, at man ville indsende ansøgning direkte til kongen, for på amtskontoret fik de kun "riebesser « ${ }^{54}$, og det bare var forgæeves, når de bad om en resolution. Den anden i forhøret, David Willatzen fra Kastvrå, optrådte rasende og trodsig, syntes Møsting. På spørgsmålet, hvad han hed, svarede han "et sær Navn« - og blev kun med besvær bragt til at røbe sit navn. Tilmed erklærede han, at selv kongen ikke havde magt til at befale sine undersåtter noget om kirkeskikken. ${ }^{55}$

Maugstrupperne frafaldt $\mathrm{i}$ første omgang deres ansøgning, men i maj kom de igen, nu med 77 underskrifter. De tilbageholdt dele af deres pinseoffer til præsten og sendte en repræsentant til Tyske Kancelli $\mathrm{i}$ København for at tale deres sag. 


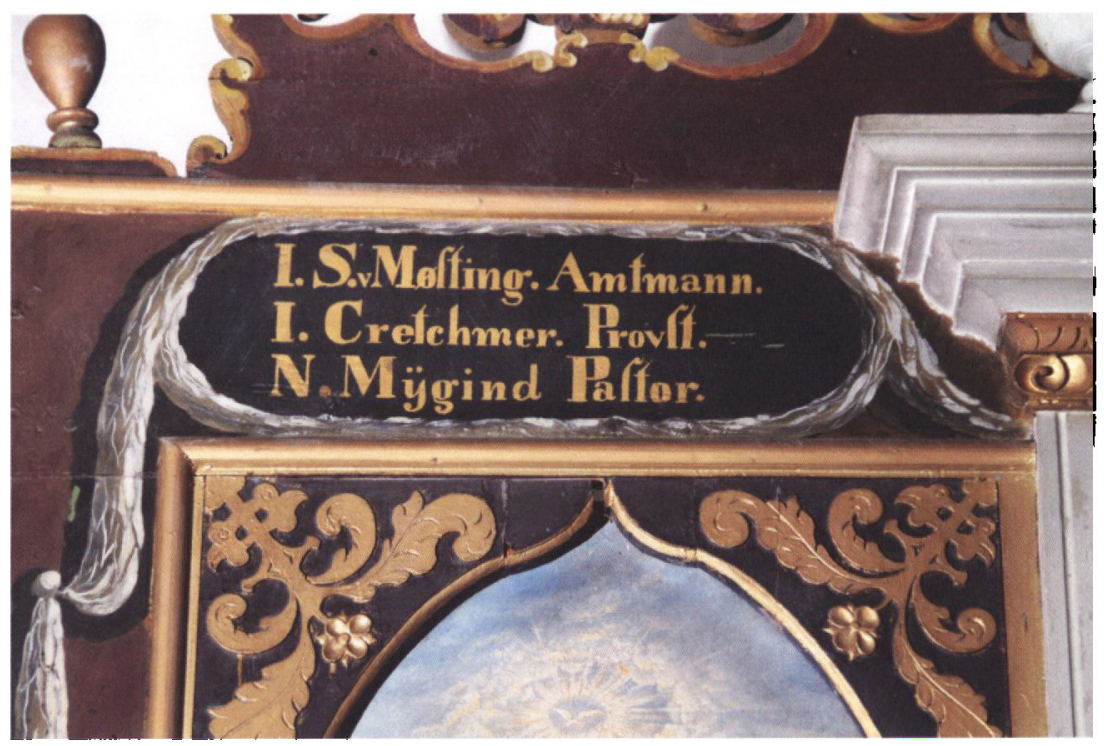

I 1797 blev altertavlen i Frørup genopmalet, og ved den lejlighed blev de daværende kirkelige myndighedspersoners navne malet $i$ guldbogstaver øverst på fløjene. Den gamle provst Joachim Cretschmer og hans energiske medvisitator amtmand Møsting, talsmand for en fast og oplyst statsmagt og en moderne liturgi, deler brædt med den uforfærdede pietistisk-herrnhutiske agendemodstander Niels Mygind. Som sognepræst snoede han sig uden om amtmandens direktiver og saboterede den nye liturgi godt stottet af sin menighed. Foto: Martin Bo Nørregard.

\section{Sogneafstemninger}

Januar-februar var den kaotiske protests tid. Da nyheden om 26. januar-patentet for alvor kom ud, og da nogle præster fra marts måned valgte at læse det op fra prædikestolen, fik menighederne mere fast grund under fødderne. De havde nu kongens ord for, at husfædrene kunne stemme om, hvorvidt de onskede gammel eller ny ordning, »kun skal deres tilkendegivelser på lovmæssig og sømmelig måde bringes frem for øvrigheden, som underretter præsten og bestemmer hans optræden.« Menighed efter menighed benyttede sig af muligheden. Der blev indsamlet underskrifter for at bevare den gamle kirkeskik, og papirerne blev sendt til amtet med bøn om, at den nye agende blev opgivet: 


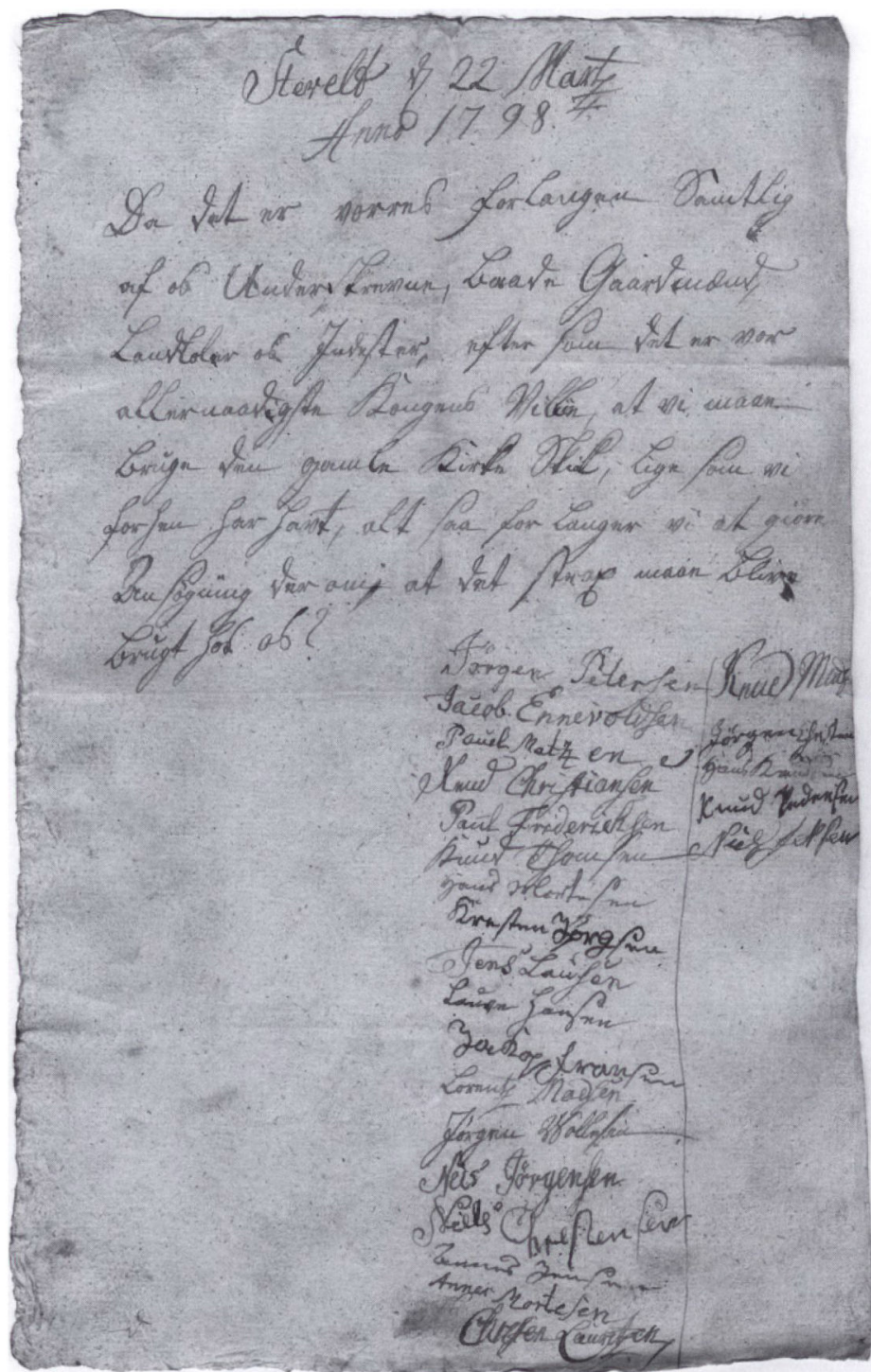

Protest fra Stevelt $i$ Øsby Sogn. Mellem marts og maj 1798 protesterede alle sogne $i$ Haderslev Herred bortset fra Gl. Haderslev og Vonsbak mod den nye liturgi. De fleste påberabte sig kongens patent af 26. januar. I Stevelt talte beboerne meget selvbevidst den 22. marts 1798: "Da det er vorres forlangen samtlig af os underskrevne, baade gaardmand, landboler og indester, efter som det er vor allernaadigste kongens villie, at vi maae bruge den gamle kirke skik, lige som vi forhen har havt, alt saa forlanger vi at giore ansøgning derom, at det strax maae blive brugt hos os ...". 
Underskriftlister til amt og provst til fordel for gammel kirkeskik

$16 / 21798$ Sommersted

4/3 1798 Stepping

11/3 1798 Frørup

25/3 1798 Starup-Grarup 26/3 1798 Øsby

$28 / 31798$ Ødis

4/4 1798 Stenderup

$11 / 41798$ Jels

5/4 1798 Bjert

efter 10/4 1798 Halk

21/4 1798 Sdr. Vilstrup

21/4 1798 Vonsild-Dalby

27/4 1798 Oksenvad

28/4 1798 Hejls

5/5 1798 Vejstrup

7/5 1798 Skodborg

7/5 1798 Maugstrup

15/5 1798 Hammelev

21/5 1798 Moltrup-Bjerning

21/5 1798 Fjelstrup samtlige indvånere, 90 navne (heraf to kvinder)

pastor Mygind på alle sognemænds vegne bortset fra en til to pastor Mygind på alle sognemænds vegne bortset fra en samtlige indvånere, 118 navne samtlige indvånere, 172 navne (heraf ni kvinder)

for alle i sognet bortset fra 7, 89 navne (heraf en enke)

62 navne

75 navne (heraf en enke)

størstedelen af husfædrene, 88

navne

samtlige i menigheden, 98 navne (heraf en enke)

alle i sognet, 125 navne (heraf fire enker)

sognerepræsentanter for alle, Dalby

13 , Vonsild 10 navne

otte fuldmægtige for et enstemmigt sogn

55 navne

skrevet af tidl. sognefoged Peter

Iversen, 72 navne (heraf syv enker, tre med ført hånd)

for hele sognet, 77 navne (heraf en enke)

næsten alle husfædre, 77 navne Bragt til København af budbringer enigt sogn, 91 navne (heraf tre enker)

seks fuldmægtige for begge menigheder

fem af kirkeværger og 12-mænd for alle 
VÆRDIKAMP PÅ REVOLUTIONSTIDEN

113

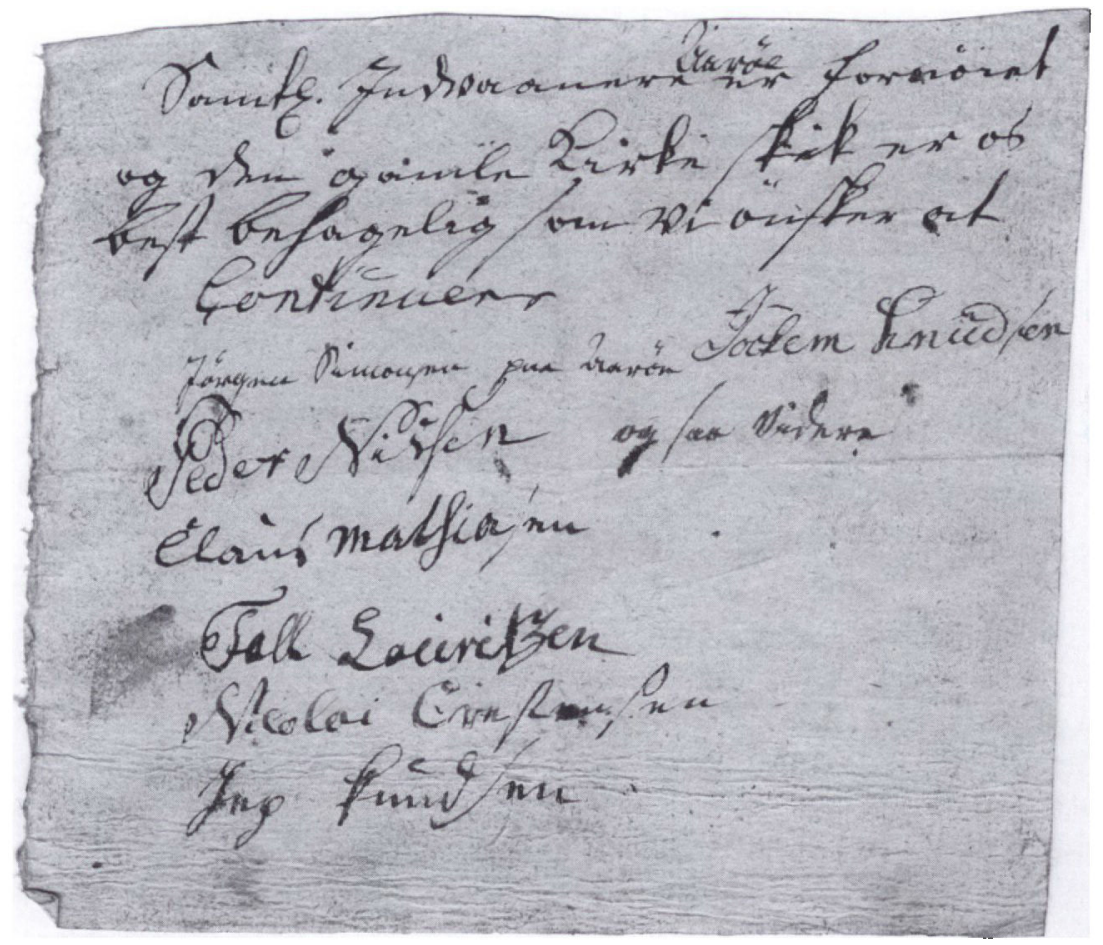

Nogle protester var skrevet på små papirlapper. Den udaterede liste fra øen Åro er fra 22.-23. marts 1798 og lyder: "Samtl. indwaanere er fornøiet og den gamle kirkeskik er os best behagelig som vi onsker at continuere...".

6/9 1798 Åstrup

9/9 1798 Fjelstrup

u. dato Taps sognepræst til amtmand: et flertal ønsker gl. agende

gentaget anmodning for alle i sognet, 108 navne

samtlige indbyggere, 60 navne

Ansøgerne henviste til lovens ord og kongens vilje: »Da Guds Ord lærer os at være Kongen og Hans Befalingsmænd lydig, saa har vi ogsaa tiet stille og benyttet os af den nye Kirkeorden saa got vi har kundet; men da vi hører at Kongen er saa naadig og stiller det $\mathbf{i}$ Meenighedernes frie Villie, om de vil bruge det nye eller det gamle, naar de derom for den vedkommende Øvrighed giver deres Mening 
paa en anstændig Maade til kende; saa ønsker vi eenstemmig i begge Sogne det Gamle, « hed det i henvendelsen fra Vonsild-Dalby 21. april 1798.

Afstemningerne omfattede husfædre. Enkelte enker og nogle få andre kvinder optræder også på listerne, og det var ikke kun gårdejere, som kom til orde. Bredden i afstemningerne blev fremhævet gang på gang, f.eks. i Ødis: "Samtlige underskrevne af Ødis Sogn, både store og små«, eller i Stevelt i Øsby Sogn: "Både gårdmænd, landboler og indester «. Alle lister var vendt mod agenden, kun i ét tilfælde (Sdr. Vilstrup) rummede papirerne oprindeligt en kolonne til folk, som ville sige ja til den nye agende, men den forblev uudfyldt.

\section{Præsternes reaktion}

Hvordan tog præsterne mod tilkendegivelserne? Nogle præster var realister og anbefalede amtet at vise imødekommenhed; de ville have ro og frygtede for deres indtægter: "Det går dog i længden ikke med det nye, " mente Peter Feddersen i Vonsild-Dalby. "Og hvilken tung luft er der ikke i kirken for præsten, når han ser og føler misfornøjelse fra alles ansigter!! Jeg ønsker at tilbringe de resterende få dage af mit liv i fred med mine tilhørere og så vidt muligt også at være dem til nytte; misfornøjede hjerter er også lukkede hjerter. Nådige Herre, læg nu ikke hindringer $\mathrm{i}$ vejen for mit embede og tag besindigt mod dette, " skrev han anbefalende til Møsting. ${ }^{56}$ Kollegaen Matthias Gottlieb Chemnitz i Ødis var af samme mening. Alle hans sognebørn var for det gamle, og "hans egen lykke i denne verden afhang meget af stemningen i menigheden, « skrev han til sin amtmand. ${ }^{57}$

Andre præster følte sig højt hævet over den uvidende menighed. I Stenderup underskrev 66 husfædre i sognet et andragende til støtte for den gamle orden. Få dage inden mente deres præst, J. Chr. Jessen, at det kun var få, som var imod det nye, og de var folk uden en ren, forbedret smag og indsigt i religionssager, eller de var uinteresserede eller dumdristige "raisonneurs", som spottede alt nyt. Dem lyttede han ikke til, men frygtede dog, at det kongelige patent skulle lede de usikre på afveje. ${ }^{58}$ Det fik han jo ret $i$.

Kløften mellem præst og menighed var ofte dyb. I Hejls undertegnede 55 husfædre den 28. april 1798 en bønskrivelse til amtmand og provst om at måtte få den gamle kirkeskik igen. Da det ikke fik nogen følger, og da menigheden så klagede på et grandemøde i præstegår- 
den 28. december, fik de til svar, at den sag måtte de diskutere med amtet. Den 29. december sendte Hejls-folkene så for anden gang en protest til amtmand og provst. De anførte, at kongens forordning overlod valget til menighedens frie vilje - men præsten lyttede ikke til dem og ville tvinge dem. Ej heller det nyttede. For tredje gang klagede de så den 21. januar 1799 til amtmand og provst, og nu føjede de en trussel til: »Får vi ikke endnu i dag en afgørelse fra Deres højvelbårenheder, at vi forskånes for den nye kirkeagende, og at det helt og fuldt skal blive på gammel fod, så må vi allerunderdanigst vende os til tronen for at udvirke en sådan allerhøjeste resolution."

Hejls-præsten berettede, at der var højrøstet modstand. Der blev truet med uro, hvis ønskerne ikke blev fulgt, og de utilfredse ville søge altergang $i$ andre kirker. "Vores præst skal tage sig $\mathrm{i}$ agt, " sagde skrædder Nis Hansen, "at det ikke går ham sådan i Hejls som engang en præst i Vejstrup, som blev dræbt i kirken i tårnvinduet“. Præsten indberettede, at da folkene var samlet til sneskovling, steg uroen til rasende højde, og efter masser af brændevin blev aftalt, at man ikke skulle betale noget til præst og degn. Præsten var forarget, for her kom folket og ville fortælle ham, hvad han skulle forkynde som kristendom. ${ }^{59}$

\section{Møstings reaktion}

Inde i Haderslev var især amtmanden og mere afdæmpet provsten helt på linje med de præster, som forsvarede agenden. Møstings klare mål var at redde agenden. Efter hans vurdering havde alle menigheder bortset fra Stepping-Frørup ved nytår 1798 taget nyordningen til sig uden protest. Det kunne der ikke ændres ved, og januar-patentets tilladelse til afstemning gjaldt derfor efter hans tolkning ikke her. Når nyordningen én gang var indført, var det ikke muligt at gå tilbage. Den enkelte i menighederne havde fri adgang til at vælge de gamle formularer for sine egne kirkelige handlinger, og gamle tekster kunne bruges sideløbende med de nye, men den fælles gudstjeneste som sådan skulle følge agendens forskrift, hvor denne én gang var indført. Afstemninger kunne ikke komme på tale, og blev de alligevel foretaget, kunne de negligeres, mente Møsting. Underskriftlisterne kunne han slet ikke tillægge værdi. De indeholdt »tilføjede (nachgeschriebene), åbenbart falske navne«, mente han og reagerede derfor ikke på de mange lister. "Jeg har valgt den holdning, ikke at give de klagende 


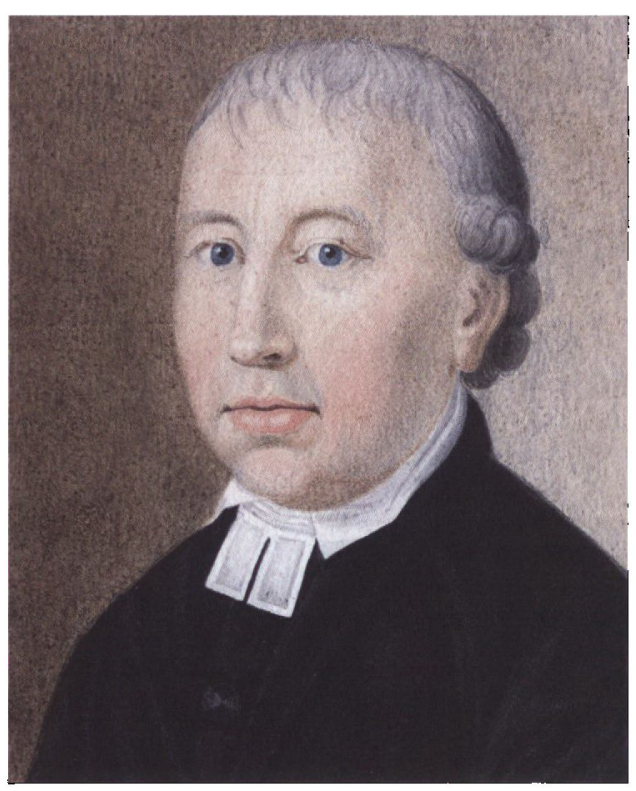

Adolf Heinrich Strodtmann, forstepræst og provst $i$ Haderslev 1798-1839. Kirkehistorikere har ofte fremhavet, at Strodtmann var en rationalist of oplysningsmand, hvis støtte til den moderne liturgi var medvirkende til striden med det konservative kirkefolk $i$ provstiet. En udpræget oplysningsven som pastor Prahl $i$ Vedsted var nu ikke imponeret af Strodtmanns indsats. I et brev til Adler skrev Prahl 1799, at det ene og alene skyldtes den "brave, standhaftige og uforfærdede amtmand Mosting, at den stakkels kirkeagende ikke er endnu rent forjaget og fredlyst hos os «. Andre kilder bekræfter, at Strodtmann stod helt $i$ skyggen af amtmanden. Oliemaleri $i$ Museum Senderjylland - Arkæologi Haderslev.

nogen resolution, men at holde dem hen," skrev han åbenhjertigt til Adler ${ }^{60}$ Han håbede, at folk ville miste interessen for sagen, når forårets og sommerens markarbejde gav dem andet at bestille.

Afstemninger var fordærvelige, mente Møsting. Han redegjorde for sit synspunkt til Tyske Kancelli den 23. marts 1798: "Ved en afstemning vil der altid komme delte meninger og derfor opstå flere slags gudstjenester. Der vil i hver menighed opstå to religiøse partier, som vil leve i erklæret afsondring og modvilje mod hinanden. Det vil ødelægge den fælles opbyggelse, målet for den fælles gudstjeneste. End ikke den enkeltes sande mening vil komme frem ved en afstemning. En stor del af landboerne, i det mindste i dette provsti, har slet ingen selvstændig mening, men befinder sig i en intellektuel og moralsk umyndighed. Når bortses fra deres personlige forretninger, tænker og handler de kun sådan, som de ledes af andre. Den sunde menneskeforstand får dem ganske vist meget ofte til at erkende det bedre som bedre; men kommer der en partistifter, som buldrer, skælder ud og truer på disse folks måde, så lader de sagen være god og siger ja til det, han byder på, for at få fred eller af frygt.« I alle tilfælde kunne en afstemnings resultat ikke gælde evigt, for menigheden ændrede sig jo hele tiden. ${ }^{61}$ 
Når Møsting saboterede afstemningerne, var han på kollisionskurs med Tyske Kancelli. Derfor fandt han det nødvendigt at skaffe sig støtte i de højeste kredse. Han skrev til hertug Frederik Christian af Augustenborg, som sad i statsrådet og gennem sin hustru Louise Augusta var svoger til kronprinsen, og her mødte han forståelse. Hertugen gav ham ret $i$, at intet var mere skadeligt end disse afstemninger, som Cay Reventlow havde legaliseret. De fostrede egenrådighed og opsætsighed hos menigmand, og de svækkede øvrighedens autoritet. De førte til absurditeter, og den skiftende brug af gammel og ny liturgi fremkaldte sekterisk ånd og religionssplittelse $\mathrm{i}$ adskillige menigheder. Kronprins Frederik var enig og gav over for Cay Reventlow udtryk for, at man havde båret sig forkert ad, og at der skulle ske ændringer. ${ }^{62}$ Så vidt vides, rokkede det dog ikke stemningen $\mathrm{i}$ kancelliet.

\section{Appel direkte til kongen}

Fra Møsting fik sognefolkene, som nævnt, ikke svar, når de kom med deres andragender. De vidste, at deres afstemningslister blot blev lagt i arkivskabet i amtshuset. Derfor skrev de selvbevidste folk direkte til kongen. Det gjorde:

$17 / 31798$ Aller

4/4 1798 Hoptrup

af $10 / 41798$ Vedsted

16/6 1798 Vedsted

23/5 1798 Moltrup-Bjerning

16/11 1798 Hammelev

19/11 1798 Vedsted samtlige beboere, 73 navne

ti sogneforstandere for 175 navne (10 ville ikke underskrive)

tre befuldmægtigede på vegne af samtlige, mere end 70; ca. 20 har ikke villet stemme

to befuldmægtigede gentager ansøgning $10 / 4$

seks fuldmægtige for begge sogne undtagen nogle få

samtlige sognefæller, 91 navne (som 15/5 1798) (heraf fire kvinder/enker), overbragt til $\mathrm{Kbh}$. af skrædder Christian Rasmussen Börling fra Vejbøl gentager to tidligere ansøgninger, 69 navne (en kun forbogstaver), overbragt til Kbh. af skrædder Christian Rasmussen Börling fra Vejbøl 
Skrivelserne blev sendt til Tyske Kancelli i Den røde Bygning på Slotsholmen. Her gik de ind i det kringlede statsmaskineri. De blev sendt videre til Overkonsistoriet i Slesvig, og herfra videre til Møsting og hans provst, som hver gang blev bedt om at foretage en undersøgelse, så en endelig afgørelse kunne træffes og meddeles ansøgerne fra kongen. Som regel strandede papirerne blot, når de nåede til amtshuset. Vedsted-ansøgningen kan tjene som eksempel. Deres sognepræst Peter Prahl havde ikke været til sinds at opgive agenden, og det fik menigheden til at klage til kongen den 10. april. Da det ikke førte til svar, skrev de igen. For en gangs skyld reagerede amtmanden, sammen med provsten. Den 28. september 1798 modtog klagerne et nej: Agenden var blevet indført i sognet først på året, ansøgningen var ikke enstemmig, og den "svarede ikke til den sande mening i patentet, " hed det $\mathrm{i}$ afslaget. ${ }^{63}$ Det fremkaldte endnu en klage den 19. november til kongen, og denne gang sluttede Hammelev Sogn sig til. For at være sikre på svar sendte de denne gang brevet til København med en personlig budbringer. Landskræedder Christian Rasmussen Börling fra Vejbøl rejste med klagerne fra Vedsted og Hammelev og overrakte dem personligt i kancelliet og bad om svar. Det fik han nu ikke, kun det mundtlige tilsagn, at afsenderne ville få svar fra Overkonsistoriet eller amtet. Igen gav Møsting sig god tid, da han fik klagen til udtalelse. Den 2. januar 1799 rykkede skrædderen amtet for svar. ${ }^{64} \mathrm{I}$ april havde pastor Prahl ikke hørt noget om et resultat på klagen. Så han holdt sin gudstjeneste som hidtil, ganske uanset menighedens protest. ${ }^{65}$

Møsting nærede en dyb skepsis over for disse folkelige kræfter. Det kom f.eks. frem i kontroversen med Maugstrup-folkene. Her var konflikten endt med, at sognefolkene tilbageholdt en del af pinseofferet til præsten. De sendte en lokal skrædder til kancelliet med klage over den nye agende, og han blev modtaget af konferensråd Kristian Ludvig Schütz. De to fik en længere snak. »Deres gesandt var en meget beskeden og godmodig mand. Min tiltale gjorde sådant indtryk på ham, at han udgød varme tårer, «skrev den høje embedsmand til Møsting. Det ville slet ikke være kommet til konflikt, hvis præsten havde vist sig mindre stivsindet og mere havde fulgt regeringens faderlige besindighed, hvis mål var at stille stormen ved uden tvang at forene nyt og gammelt, mente Schütz. Stemmesamlingen kunne ikke standses, og desuden ville den ikke gøre skade. Det gjaldt om at opretholde roen. Sådan var tonen i kancelliet. 
Møsting var helt uenig. Han fandt Schütz dybt naiv og gav Maugstrupskrædderen et helt andet skudsmål: Schütz var ført bag lyset, manden var et elendigt og slet menneske, som ikke var den viste godhed værd. Skrædderen var kendt for at hjemsøge de lokale kroer, hvor han fortalte, at amtmand og provst ville blive draget til ansvar, at de ville blive tvunget til at indføre den gamle orden, at den nye agende ikke var regeringens og kongens værk, kun udtænkt af amtmanden. Hvis slige historier blev udbredt, ville det forlede andre sogne til at sende lignende deputerede til København. Det kunne give departementet nok at gøre, hvis man var så venlig som over for manden fra Maugstrup. Men hvis de lokale kværulanter drog til København, ville Møsting jo blive fri for at skulle føre lange samtaler med den slags folk lokalt, tilføjede han ironisk. Om regeringens besindighed ("Gleichmütigkeit") ville bringe nytte eller skade, det ville tiden vise, sluttede Møsting. I øvrigt kunne Schütz roligt overlade klagesagerne til Møsting, for han kendte præster og folk bedre end de høje herrer i København. ${ }^{66}$

\section{Et år efter}

Hvad kom der ud af menighedernes afstemninger og protester? I september 1799 var generalsuperintenden på visitats i Haderslev Provsti. Agendens forfatter drog fra sogn til sogn for at påhøre præstens prædiken, lade børnene overhøre og i øvrigt tilse kirken, skolen og fattigvæsenet og deres økonomi. Hver præst afleverede en beretning om de ændringer, som var forekommet i kirke- og skolevæsenet siden sidst. $^{67}$

Samstemmende berettede præsterne, at de havde taget nyordningen i brug ved nytår 1798 som foreskrevet, og i almindelighed havde menighederne forholdt sig rolige de første søndage. Fra marts havde de dog meldt sig med indvendinger. De havde hørt, at andre sogne protesterede med godt resultat, og at det kongelige patent gav dem ret til at holde afstemning, og de krævede fornyelserne lagt på hylden. Herefter havde de fleste præster valgt at komme ansøgerne $i$ møde for at undgå uro og måske også for at slippe for problemer med offerbetalingen. I 1799 var stillingen, at gudstjenesten de fleste steder var vendt tilbage til det gammelkendte, dog havde nogle præster reddet enkelte markante fornyelser fra det nye ritual; bønner og tekster blev kun undtagelsesvist messet, fadervor blev kun bedt én 
gang, efter prædiken, salmevalget var mere varieret end for, og det private skriftemål var afløst af almindeligt skriftemål som forberedelse til altergang. Ganske få præster havde kunnet fastholde den ny liturgi næsten helt.

I Vedsted, hvor menigheden havde protesteret så markant, berettede oplysningspræsten Peter Prahl, at han kun afveg fra det nye ritual, hvor det udtrykkeligt blev forlangt. Ved skriftemål benyttede han dog endnu håndspålæggelse, og han havde været nødt til at supplere de nye prædikentekster med oplæsning af de gammelkendte evangelietekster. Adlers nye salmebog vovede han ikke at tage i brug. "Jeg frygter, at hvis jeg begynder med det for naboerne, så bliver gemytterne urolige, og den nu undertrykte partiånd vil komme til live igen og blæse alarm. «Den vedholdende præst havde haft held til at dreje sin menighed efter sine ønsker. En sådan mand fik biskoppens ros. Efter visitatsen i 1802 skrev Adler om Prahl: "Præsten har gjort sig meget fortjent for oplysningen i denne menighed. Ikke blot den nye agende, også den nye sangbog er indført helt og fuldt. ${ }^{68}$

Gudstjenesten var med andre ord ikke blevet reformeret helt efter agendens ord, men ganske meget var dog blevet smuglet ind og blev fastholdt, sådan som moderne tænkende præster havde onsket det.

\section{Facit og perspektiv}

Striden i Haderslev Amt om en ny gudstjenesteorden blev en episode, men den var del af en større helhed. Uroen greb de fleste egne af Sonderjylland. I Ensted Sogn f.eks. opstod en sådan uoverensstemmelse mellem pastor Freuchen og befolkningen, at præsten valgte at gå på pension. ${ }^{69}$ Da præsten i Bov benyttede de nye tekster, fik to kirkeværger sognefolkene til at nægte præsten offer, de blev fængslet, og 100 bønder protesterede ved at møde op på amtshuset i Flensborg. ${ }^{70}$ Fra Broager rejste to deputerede til København med et bønskrift underskrevet af 350 personer, og det kom til gentagne tumulter i Sønderborg amtshus. ${ }^{71}$ I Angel så det først ud, som om mange sogne accepterede nyordningen, men i 1798 blev modstanden almindelig udbredt, og ligesom i Tyrstrup Herred lagde sognerepræsentanter fra flere sogne fællesråd op mod agenden. Når det gjaldt landboreformer og økonomi, var Angel-bønderne med på reformer, men kirkeligt var de konservative. ${ }^{72}$ I gestsognene var modstanden så udbredt, at præ- 


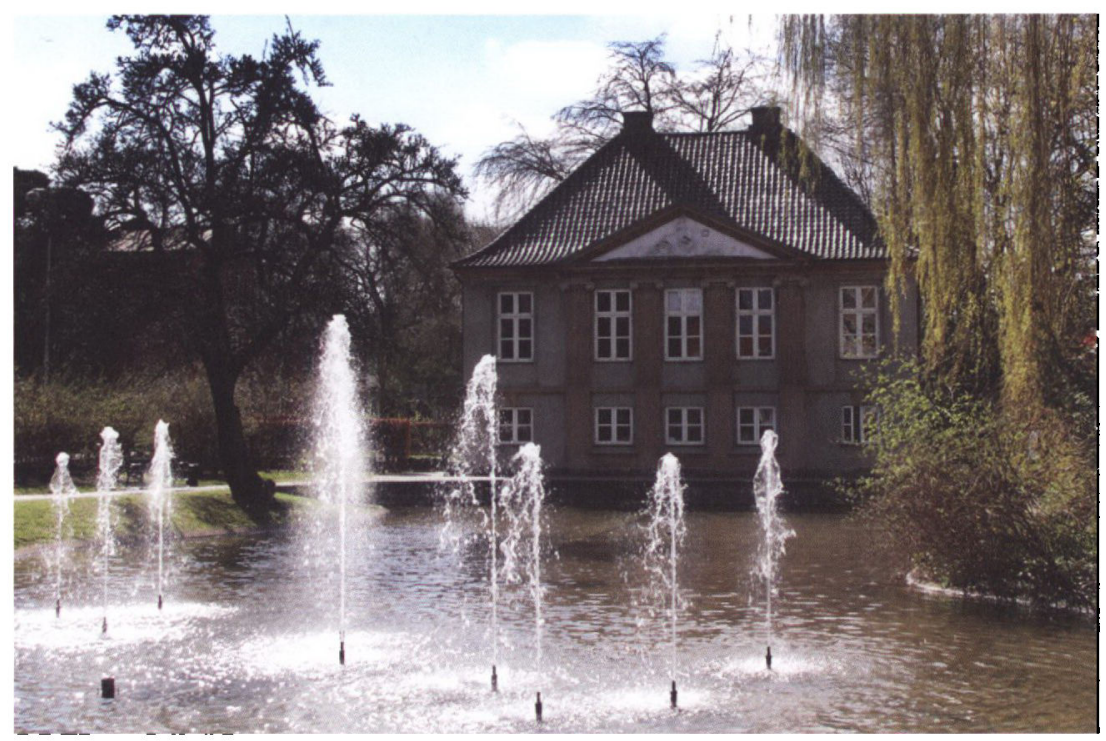

Da Møsting $i 1804$ blev forfremmet til præsident for Tyske Kancelli $i$ Kobenhavn, hertugdømmernes øverste civile myndighed, købte han et fornemt byhus $i$ Smallegade på Frederiksberg som sommerbolig. Huset var opfort $i 1800$ med forbillede $i$ den berømte arkitekt C.F. Harsdorffs hus på Kongens Nytorv, som fra 1795 dannede monster for mange fornemme byhuse $i$ hovedstaden. Et relief af gudinden Flora pryder trekantfrontonen over murfremspringet $i$ midten med de fire joniske pilastre. Mosting og hans frue benyttede huset helt til statsministerens dod $i$ 1843. Huset blev nedrevet $i$ 1959, men er $i$ dag genopfort på Andebakkestien på Frederiksberg. Foto: Martin Bo Norregård.

sterne i bedste fald ikke nåede længere end til at ændre dele af gudstjenesten.

"Spørgsmålet om årsagerne til, at denne eller hin menighed eller deres forstandere erklærer sig mod de nye kirkelige indretninger fortjener den mest omhyggelige undersøgelse og overvejelse, « skrev biskop Adler i sit brev til Cay Reventlow den 27. december 1797, og det gælder også i dag. Hvor langt gik det kirkelige engagement? Befolkningen hang ved de gammelkendte tekster og salmer, ved velsignelsen og fadervor og ved privat skriftemål med syndsforladelse og altergang. ${ }^{73}$ "Man berøver os Guds rene ord, præsten følger ikke længere Luthers ord om frelsen ved troen alene, fornyelsen fjerner os fra Luther og Apostlene, " lød det fra mange menigheder, som følte sig skræmt af ændringer af det tilvante i kirken. Men det kræver en langt større undersøgelse end denne at afklare, hvor dybt de rent kirkelige 


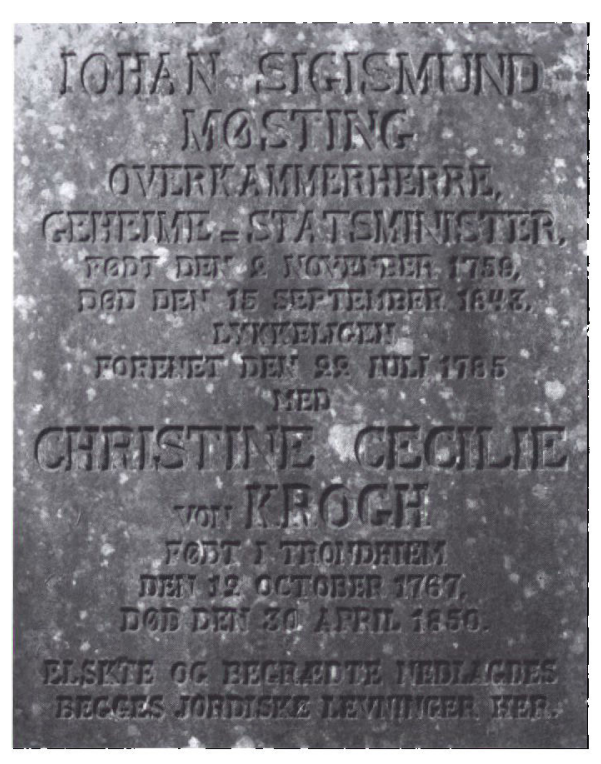

Møstings og hans hustrus gravsted på Frederiksberg gamle kirkegård dækkes af en ganske enkel gravsten. Under den छkonomiske krise efter Englandskrigen havde Møsting stået for en stram sparepolitik. Gennem 60 år var han statens flittige embedsmand, og han bevarede sin politiske indflydelse så længe, Frederik 6. levede. Foto: Martin Bo Nørregård.

overvejelser stak hos de protesterende. Tillagde befolkningen blot de kendte ord magisk kraft, eller stak der væsentligt mere i protesten?

Efter alt at domme havde initiativerne rod i befolkningen selv, det ene sogn inspirerede det andet. Reventlow-kredsen stod bag en enkelt pjece vendt mod agenden, men der er ikke fundet tegn på, at dette direkte har påvirket befolkningen. Afgørende har derimod været, at regeringen fra december 1798 viste en usædvanlig vankelmodighed. Hvornår tidligere havde regeringen forkyndt, at samvittighedsfriheden skulle være styrende princip, og hvornår før havde befolkningen haft mulighed for at ytre sig gennem afstemning om et samfundsanliggende? Befolkningen benyttede sig af den uventede ventil, så snart den blev åbnet, og det vendte op og ned på forholdet mellem undersåtter og myndigheder.

En samvittighedsfuld embedsmand som Møsting kom i en helt usædvanlig situation. Det var hans opgave at sikre fasthed, ro og orden. Efter hans opfattelse var en stor del af landboerne ganske uselvstændige. De levede $\mathrm{i}$ intellektuel og moralsk umyndighed. I sager ud over de daglige gøremål tænkte og handlede de kun, som de blev ledt af andre. Øvrigheden måtte sørge for, at "ondsindede folk og uroskabere ikke fik chance for at trænge sig ind på de fornuftige landboere. Afstemninger ville blot fore til opsplitning i partier, 
ville skabe uenighed og ville aldrig kunne afdække landboernes sande mening, fordi de $\mathrm{i}$ en sådan situation ikke var i stand til at tænke selvstændigt, men blev forledt af de ondsindede opviglere, som trængte ind på dem.

Regeringens ulyksalige vankelmod berøvede embedsmændene rygstødet i en fast lovgivning. Da amtmand Blücher i Bredsted valgte at fængsle en af Okholm-kritikerne, blev han underkendt af administrationen. Da amtmand Møsting onskede en respektindgydende straf over et par sognefogeder, som havde indkaldt deres kolleger fra et helt herred til fællesmøde, blev han nærmest saboteret af sine overordnede. Da han i maj 1798 forsøgte at redde agenden ved at foreslå kancelliet at udstede en kongelig kancellibekendtgørelse direkte til amtsbefolkningen om, at gudstjenesten som sådan skulle følge nyordningen, men den enkelte i øvrigt frit kunne vælge de gamle ordninger for kirkelige handlinger angående sig selv, fik han ikke noget svar. Det følte han som totalt uholdbart, han så sin autoritet skadet af regeringens optræden. Han fulgte i stedet sin private politik for at omgå regeringens principløshed.

Den tyske forsker Hans Beyer mente, at regeringens mærkelige vankelmodighed i 1797-98 fik følger langt ned i tiden. Den rystede landbefolkningens tillid til kongen og viste grænserne for kongens magt, den styrkede befolkningens selvbevidsthed. Da så statsbankerotten kom til i 1813, fik loyaliteten i den ellers konservative og statsloyale slesvigske befolkning endnu et stød. Det blev baggrunden for, at store dele af landbefolkningen i 1840'erne blev modtagelige for det statsopløsende slesvig-holstenske røre. ${ }^{74}$ Tesen er interessant, men kan næppe stå for en nærmere prøvelse.

Andre ingredienser $\mathrm{i}$ agendestriden peger imidlertid uden tvivl fremad. Også tidligere havde menigheder vidst at fremføre deres mening helt op til kancelliet i Kobenhavn. ${ }^{75}$ Alligevel er 1797-98-episoden første eksempel på, at et bredt flertal af landbefolkningen afholdt møder og afstemninger og tilkendegav en mening om et fællesanliggende, som rakte ud over de normale landsbyanliggender. Med ganske få undtagelser kunne landboerne læse og selv sætte deres autograf på bønskrifterne, de førende folk fulgte med i aviser og nyhedskilder, nogle var $\mathrm{i}$ stand til at gå $\mathrm{i}$ dialog med deres præster om kirkelige forhold. Proceduren med landsbymøder og bønskrifter og afstemning blev indledt på lokalt initiativ, det var ikke en idé, som kom udefra. Da januarpatentet 1798 overraskende sanktionerede den- 
ne form for tilkendegivelse, blev midlet taget $\mathrm{i}$ anvendelse over en bred front. Sognefolkene var ikke umælende undersåtter. De optrådte selvbevidst og selvstændigt og affandt sig ikke uden videre i et afslag. De lod sig ikke affærdige af deres lokale øvrighed. De viste potentiale som statsborgere.

Afstemningerne $i$ agendesagen pegede fremad. Valg til offentlige forsamlinger og udbredte indsamlinger af underskrifter om offentlige spørgsmål kendes ellers først fra 1830'erne, da stænderforsamlinger og de sprogligt-nationale spørgsmål kom på dagsordenen. ${ }^{76}$ Agendestriden viser, at forudsætningerne for en senere tids demokratiske tilkendegivelser var til stede allerede i 1790'erne.

\section{FORKORTELSER}

Chron. Samml. Chronologische Sammlung der ... Königlichen Verordnungen LASH

LAÅB

Prov. Ber.

$\mathrm{S} ø \mathrm{M}$

Sjy Årb und Verfügungen für die Herzogtümer Schleswig und Holstein ... Landesarchiv Schleswig-Holstein, Slesvig Landsarkivet for Sønderjylland, Aabenraa Schleswig-Holsteinische Provinzialberichte Sonderjysk Månedsskrift Sønderjyske Årbøger

\section{NOTER}

1. Visitatsberetninger 1799, LAÅB Generalsuperintendenten 1, Visitation Haderslev bilag E, G, $\mathrm{H}$ og KK.

2. Fldre litteratur om agendestriden er anført i F. Witt: Quellen und Bearbeitungen der schleswig-holsteinischen Kirchengeschichte, 2. udg. Kiel $1913 \mathrm{~s}$. 249-253. Derefter bl.a. H. Hejselbjerg Paulsen: "Oplysningstiden i Hertugdømmerne« II-IV, SIy Årb 1934 og 1935; Hans Beyer: „Die Geestbauern und Adlers Kirchenagende 1797-1800 i Jahrbuch fiur die Schleswigsche Geest 1955, s. 23-31; samme: "Landvolk und Geistlichkeit Angelns im Kampf um die Adlersche Agende" i Jahrbuch des Angler Heimatvereins 1955, s. 88-110, og samme: "Eckernfördes Landvolk im Kampf um den walten Glauben" (1797/ 1800) « i Jahrbuch der Heimatgemeinschaft des Kreises Eckernförde 1954, s. 716; Günter Weitling: Fra Ansgar til Kaftan, 2005, s. 254-261. Hovedkilden til artiklen her er amtmand Mø- stings papirer om striden, LAÅB Haderslev Amt 1427. De benyttes her for farste gang.

3. Sø M 1983 s. 110.

4. Regler forelå bl.a. i Kirkeordningen 1542, i Peder Palladius' danske alterbog, i Paul Walther: Kercken Handböckchen, 1635, i Adam Olearius: Kirchenbuch, 1665 og i Glïcksburgisches kleineres Altar-Buch, 1714, se Schleswig-Holsteinische Kirchen-Geschichte Bd. 5, 1989 s. $39 \mathrm{f}$ og Hejselbjerg Paulsen, SJy Årb 1934, s. 139-146.

5. Nicolaus Oest: „Ueber Kirchenagenden« i Prov. Ber. 1794, Heft 2, s. 193207.

6. Chron. Samml. 1796 nr. 81, 2/12 1796 . Konfirmationspatent er trykt $i$ agendeudgivelsen Den Slesvig-holstenske Kirke-Agende, 1797.

7. Anndringerne er beskrevet $i$ [Peter Prahl og Jacob Boysen]: Et Ord til Lxgfolk, 1797 og af Hejselbjerg Paulsen, SIy Arb 1934 s. 164-170. 
8. 4. Mos. 6, 24-26: Herren velsigne dig og bevare dig, Herren lade sit ansigt lyse over dig og være dig nådig, Herren løfte sit åsyn på dig og give dig fred!

9. Reskript 2/12 1796, Chron. Samml. 1796 nr. 81.

10. LASH Abt. 18 nr. 46b, 46d, Abt. 65.2 nr. 8085.

11. Hejselbjerg Paulsen 1934, s. 182. LASH Abt. 65.2 nr. 8085.

12. Boysen til Møsting 4/10 1797, LAÅB Haderslev Amt 1427.

13. LAÅB Haderslev Amt 1427 , cirkulære 30/10 1797. LASH Abt. 18 nr. 18a II, s. 276, Møsting til Adler 8/11 1797 .

14. Se om Emkendorf-kredsen Otto Brandt: Geistesleben und Politik in Schleswig-Holstein um die Wende des 18. Jahrhunderts, 1927/reprint 1981 s. 202-209. Om Cay Reventlow: Louis Bobé (udg.): Reventlowske papirer bd. III (1896) s. 232 og 360.

15. LASH Abt. 18 nr. 18a I-II.

16. Reventlow til Adler 12/12 1797, LASH Abt. 18 nr. 18a II.

17. Reskript 8/12 1797, Chron. Samml. 1797 nr. 70.

18. Adler til Reventlow 27/12 1797, LASH Abt. 18 nr. 18a II.

19. LASH Abt. 18 nr. $18 a$ II, s. $335 / 346$ Møsting til Adler 24/1 og 31/1 1798 og Møsting-cirkulærer 14/1 og 29/ 11798 i LÅ̊B Haderslev Amt 1427.

20. G. Japsen: Det dansksprogede skolevæsen $i$ Sonderjylland indtil 1814, 1968, s. $284 \mathrm{f}, 288,290 \mathrm{f}$.

21. Møsting til Bjørnsen, udat. koncept (24/1 1798?), LAÅB Haderslev Amt 1427.

22. Bjørnsen til Møsting $31 / 1$ 1798, LÅ̊B Haderslev Amt 1427.

23. Møsting til Mygind, udat. koncept [26/1 1798], LAÅB Haderslev Amt 1427.

24. LAÅb Gen. Sup 1, gen. Vis. Had. 1799, bilag $\mathrm{M}$, Mygind-beretning 19/9 1799.

25. Patent 26/1 1798, Chron. Samml. 1798 nr. 6.

26. Reskript 16/2 1798, Weitling, 2005, 261.

27. Adler til Møsting 2/2 1798, LA ß̊ Haderslev Amt 1427.
28. LASH Abt. $18 \mathrm{nr}$. 18a II Mosting til Adler 12/2 1798. Jf. Hans Hejselbjerg Paulsen 1934, 189.

29. Niels Sørensen til Møsting $13 / 2$ 1798, LA ̊̊ Haderslev Amt 1427.

30. Brev fra hertug Frederik Christian til sosteren 1798, se: Hans Schulz (udg.): Briefwechsel des Herzogs Friedrich Christian zu Schleswig-Holstein-Sonderburg-Augustenburg mit König Friedrich VI von Dänemark, 1908, s. 91.

31. Adler til Mesting $2 / 2$ 1798, LA Haderslev Amt 1427.

32. Petersen til Mosting 26/3 1798, LAÅB Haderslev Amt 1427.

33. LÅ̊B Haderslev Amt 1427.

34. Cirkulære 4/2 1798, LAÅB Haderslev Amt 1427.

35. Se f.eks. bestalling for Peter Iversens efterfølger, Erik Hansen i Gronninghoved 1798, LAAB Haderslev Østre Husfogderi 6.

36. LÅ̊B Haderslev Østre Husfogderi 6.

37. Patent 11/9 1795, Chron. Samml. 1795 nr. 46.

38. Skrivelser P. Iversen og Jørgen Roy samt Fjelstrup menighed til Ty. Kanc. 10/2 1798, LASH Abt. 65.2 nr. 8085, jf. Hejselbjerg Paulsen 1934, SJy Arb s. 193.

39. LASH Äbt. 65.2 nr. 8085 Bilag 2 til Overretsskrivelse 11/4 1798.

40. Reskript 23/2 1798, LASH Abt. 65.2 nr. 8085.

41. Møsting til Adler 4/3 1798, LASH Abt. 18 nr. 18a II s. 391.

42. Mosting til Ty. Kanc. $3 / 3$ og $21 / 3$ 1798, LASH Abt. $65.2 \mathrm{nr} .8085$.

43. Masting til Bardenfleth 4/3 1798, til Cay Reventlow 31/3 1798, LAÅB Haderslev Amt 1427 (koncept) og LASH Abt. 65.2 nr. 8085.

44. Forestilling 27/4 1798, LASH Abt. 65.2 nr. 8085.

45. Protokolekstrakt $11 / 6$ 1798, LAÅB Haderslev østre husfogderi 6. Omkostningerne var ikke andet end "kørepenge« til ilbudene i februar, 8 rdl. 21skl.

46. Hejselbjerg Paulsen SJy Arb 1934 s. 195.

47. Danske provinstryk 1482-1830. En bibliografi udarbejdet af Grethe Larsen, 1989, HA 303 og Ha 307. 
48. Peter Prahl til Møsting 8/3 1798, LA ̊ B Haderslev Amt 1427.

49. Bjarnsen til Møsting $1 / 3$ 1798, LAÅB Haderslev Amt 1427.

50. Forhorsprotokol 10/3 1798, LA AB Haderslev Amt 1427.

51. Bjørnsen til Møsting 30/8 1798, LAÅB Haderslev Amt 1427.

52. Visitatsberetning 1799, LAÅB Generalsuperintenden 1, visitation Haderslev 1799 bilag $N$.

53. Maugstrup-Sommersted til kirkevisitatorer 12/2 1798, LAÅB Haderslev Amt 1427.

54. Formentlig dialektudtryk (»tomme ord «?)

55. Protokol 18/2 1798, LAÅB Haderslev Amt 1427.

56. Feddersen til Møsting 22/4 1798, LAÅB Haderslev Amt 1427.

57. Chemnitz 28/3 1798 til Møsting, LAÅB Haderslev Amt 1427.

58. J.Chr. Jessen til amtmand $11 / 31798$, LAÅB Haderslev Amt 1427.

59. Hejls-skrivelser $28 / 4$ og $29 / 12$ $1798,21 / 1$ og 24/2 1799, LAÅB Haderslev Amt 1427.

60. Møsting til Adler 21/3 1798 LASH Abt. 18 nr. 18a II s. 411.

61. Møsting til Tyske Kancelli 23/3 1798, LÅ̊B Haderslev Amt 1427.

62. Hans Schulz (udg.): Briefwechsel des Herzogs Friedrich Christian zu Schleswig - Holstein - Sonderburg - Augusten

burg mit König Friedrich VI von Dänemark, 1908, s. $90 \mathrm{f}$.

63. Kirkevisitatorer 28/9 1798 til Prahl,
LAÅB Vedsted præstearkiv $60 \mathrm{Bd} 4$ II 5.

64. Børlum til Møsting 2/1 1799, LAÅB Haderslev Amt 1427.

65. Prahl til Adler 18/4 1799, LASH Abt 18 nr. 18a II s. 545.

66. Breve Schütz til Møsting 10/7 1798 og Møsting til Schütz 21/7 1798, LÅ̊B Haderslev Amt 1427.

67. Visitatsberetninger Haderslev 1799, LA ßB Gen. sup. 1.

68. Visitatsberetning Haderslev 1802, LAÅB Gen sup 1 .

69. Lars N. Henningsen: Ensted sogns historie, 1987, s. 125; Hejselbjerg Paulsen SIy Arb 1934, s. 204.

70. Schleswig-Holsteinische Chronik 1799, Nr. 4, s. $180-182$.

71. Hejselbjerg Paulsen, SJy Årb 1934, s. 196-202.

72. Hans Beyer: "Landvolk und Geistlichkeit Angelns im Kampf um die Adlersche Agende i Jahrbuch Angeln 1955, s. 88-107.

73. Således tolket af G. Japsen: Det dansksprogede skolevæsen $i$ Sonderjylland indtil 1814, 1968, s. 298f.

74. Se Hans Beyer-artiklerne nævnt note 2.

75. Se f.eks. deputation fra Stepping til København for at få J. C. Kastrup til sognepræst 1738, Dansk præste- og sognehistorie X, A, 1977-85, s. 264.

76. Se Hans Schultz Hansen: Hjemmetyskheden $i$ Nordslesvig 1840-1867, bind 1-2, 2005, s. 58 og 369 (petitioner).

\section{Zusammenfassung}

Im Jahr 1797 wurde eine neue Kirchenordnung, eine so genannte Agende, herausgegeben zum Gebrauch in sämtlichen Kirchen in Schleswig und Holstein. Die kirchliche Neuordnung war Ausdruck aufklärerischen Gedankenguts und brach mit alten Traditionen, allerdings protestierten so viele Gemeinden, dass die Deutsche Kanzlei in Kopenhagen unter der Führung ihres neuen Chefs Cay Reventlow dazu überging, einzelnen Gemeinden ein gewisses Mitbestimmungsrecht bei der Einführung des neuen Rechts zu gewährleisten. Der vorliegende Artikel untersucht den Verlauf in der Probstei Haderslev. 
Eine selbstbewusste Bauernschaft stand dem autoritären Amtmann J.S. Møsting gegenüber. Dieser versuchte bewusst, die - in seinen Augen - staatsschädigende Kapitulation der deutschen Kanzlei vor den Unruhestiftern in der regionalen Bevölkerung zu sabotieren. Eine Gemeindemehrheit wagte es, sowohl gegen Møsting als auch gegen die Pastoren aufzubegehren. Es wurden Unterschriften gesammelt und Deputationen direkt an die Kanzlei in Kopenhagen geschickt. Dem Amtmann fiel eine Aufrechterhaltung der Autorität des Staates schwer. Der Verlauf zeigt einen staatlichen Verwaltungsapparat, der unter gewaltigem Druck steht, und eine Lokalbevölkerung, die selbstbewusst ihre eigenen Interessen vertritt. Der Streit im Gebiet Haderslev 1797-98 ist Teil einer größeren Protestbewegung und kann als Vorläufer für die frühdemokratischen Prozesse ab den 1840er Jahren gesehen werden. 
